\title{
Cenozoic tectonostratigraphic evolution and architecture of the Central Andes in northern Chile based on the Aquine region, Western Cordillera (19-19 $\left.{ }^{\circ} 30^{\prime} S\right)$
}

\author{
*Sebastián Herrera ${ }^{1}$, Luisa Pinto ${ }^{1}$, Katja Deckart ${ }^{1,2}$, \\ Javier Cortés ${ }^{1}$, Javier Ignacio Valenzuela ${ }^{1}$
}

\begin{abstract}
${ }^{1}$ Departamento de Geología, FCFM, Universidad de Chile, Plaza Ercilla 803, Casilla 13518, Correo 21, Santiago, Chile. sebherre@ing.uchile.cl; lpinto@ing.uchile.cl; kdeckart@ing.uchile.cl; jacortes@ing.uchile.cl; valenvolke@gmail.com

2 Advanced Mining Technology Center (AMTC), Universidad de Chile, Tupper 2007, Santiago, Chile.
\end{abstract}

*Corresponding author: sebherre@ing.uchile.cl

\begin{abstract}
Crustal thickening by horizontal shortening and associated deformation have been broadly considered as prime mechanisms for mountain building in the Central Andes of western South America. However, timing and structural style of Andean orogeny in northernmost Chile remains to be fully understood. By means of this contribution we attempt to unravel the Cenozoic tectonostratigraphy and structural architecture of a narrow segment within the Western Cordillera (western flank of the Altiplano plateau), based on detailed structural mapping, available and new geochronological data gathered from the Aquine region $\left(\sim 9^{\circ} 15^{\prime} \mathrm{S}\right)$. The geology of this area indicates that compressive tectonics dominated for $\sim 21 \mathrm{Myr}$, between $27 \mathrm{Ma}$ and $6 \mathrm{Ma}$, and that onset of deformation probably occurred in the middle Eocene (after $c a .49 \mathrm{Ma}$ ). According to angular unconformities registered throughout the region, three principal compressive episodes have been determined: (1) middle Eocene-late Oligocene ( $c a .49-27 \mathrm{Ma}$ ); (2) late Oligocene-middle Miocene ( $c a .27-14 \mathrm{Ma}$ ); and (3) middle-latest Miocene, 14-6 Ma. Paleogene and Neogene structural development within the Aquine region was concomitant to activity on the bordering West and East Vergent Thrust Systems (WTS and ETS), which controlled uplift of the western Altiplano since the late Oligocene-early Miocene, located at the foot of the Precordillera and within the eastern part of the Western Cordillera, respectively. Major structures in the western segment of the region are high-angle, east-vergent, substratum-involving thrusts that affect late Mesozoic and Cenozoic volcanic and sedimentary intra-arc deposits. Unalike, a west-vergent fold-and-thrust belt is developed in the southeastern segment of the region, involving only Miocene deposits. These contrasting structural styles and opposite vergences indicate a combination of thin- and thick-skinned tectonics in a "pop-up" like structural array. Growth strata and sedimentological features in alluvial and fluvial sandstones and conglomerates of the upper Miocene Mauque Formation suggest the occurrence of syntectonic deposition. In addition, gentle angular unconformities within upper Oligocene-upper Miocene arc deposits suggest that sedimentation and volcanism developed synchronic to compressive tectonics throughout the Miocene and coeval to deposition in the active bordering thrust systems (WTS and ETS). The interpreted tectonostratigraphic development of the study area is similar to but slightly diachronic with the Cenozoic evolution in the Belén region $\left(18^{\circ}-19^{\circ} \mathrm{S}\right)$ of northernmost Chile. We interpret that east- and west-vergent thrusts within the Western Cordillera, are deeply rooted in a crustal-scale "pop-up" structure that accommodated Cenozoic deformation on the western flank of the Altiplano. Uplift as a consequence of contraction along the Western Cordillera was coeval to late Paleogene block exhumation and subsequent Neogene development of fold-and-thrust belts on the eastern border of the Altiplano. The main structural characteristics within the Aquine region suggest that inversion of an Upper Cretaceous intra-arc basin was of major relevance for the Cenozoic structural development of the Western Cordillera.
\end{abstract}


RESUMEN. Evolución tectonoestratigráfica y arquitectura cenozoica de los Andes Centrales en el norte de Chile, región de Aquine, Cordillera Occidental (19-19³0'S). La deformación y el engrosamiento cortical por acortamiento horizontal han sido ampliamente considerados como mecanismos primordiales involucrados en la construcción de los Andes Centrales. No obstante, el estilo estructural y la temporalidad de la orogenia Andina en el extremo norte de Chile son aún objeto de debate. Basada en un registro detallado de la geología de la región de Aquine $\left(\sim 19^{\circ} 15^{\prime} \mathrm{S}\right)$, nuevas edades $\mathrm{U}-\mathrm{Pb}$ y la geocronología disponible, por medio de esta contribución intentamos dilucidar la tectonoestratigrafía cenozoica y la arquitectura de un angosto segmento de la Cordillera Occidental (flanco occidental del Altiplano). En esta área, la geología indica que durante $\sim 21 \mathrm{Myr}$, la región estuvo sometida a condiciones tectónicas compresivas, entre los 27 Ma y 6 Ma. Este régimen contraccional se habría iniciado durante el Eoceno medio (post- 49 Ma). De acuerdo con las discordancias angulares registradas en la región, tres episodios contraccionales han sido determinados: (1) Eoceno medio-Oligoceno tardío (ca. 49-27 Ma); (2) Oligoceno tardío-Mioceno medio ( $c a$. 27-14 Ma); y (3) Mioceno mediotardío 14-6 Ma. El desarrollo estructural Paleógeno y Neógeno asociado fue concomitante con la actividad tectónica en los sistemas regionales de cabalgamientos de vergencia al oeste (WTS) y al este (ETS), situados en los márgenes occidental y oriental de la Cordillera Occidental, respectivamente, y que controlaron el alzamiento tectónico del Altiplano occidental desde el Oligoceno tardío-Mioceno temprano. Las mayores estructuras en el segmento occidental de la región corresponden a fallas inversas de alto ángulo que involucran substrato Mesozoico y afectan a depósitos del Mesozoico tardío y depósitos sedimentarios y volcánicos del intraarco Cenozoico con una vergencia al este. De manera contrastante, una faja plegada y corrida vergente al oeste se desarrolla en el segmento suroriental de la región, deformando solo depósitos miocenos. Las vergencias y estilos contrastantes de las estructuras indican una combinación de tectónica de "piel fina" y "piel gruesa”, desarrollada en un arreglo estructural de tipo pop-up. Estratos de crecimiento y características sedimentológicas asociadas a depositación sintectónica en areniscas y conglomerados aluviales y fluviales de la Formación Mauque (Mioceno superior), además de suaves discordancias angulares entre depósitos del arco Oligoceno superior-Mioceno sugieren que la sedimentación y el volcanismo ocurrieron sincrónicos a la tectónica compresiva y a la depositación asociada a los sistemas estructurales regionales marginales activos (WTS y ETS). La evolución tectonoestratigráfica interpretada para la región es similar, aunque levemente diacrónica a la evolución cenozoica de la región de Belén $\left(18^{\circ}-19^{\circ} \mathrm{S}\right)$, en el extremo norte de Chile. Interpretamos que las fallas inversas de la Cordillera Occidental, vergentes al este y al oeste, están enraizadas en una estructura tipo pop-up de escala cortical que acomodó deformación Cenozoica en el flanco occidental del Altiplano. El alzamiento originado por contracción a lo largo de la Cordillera Occidental fue coetáneo a la exhumación de bloques durante el Paleógeno tardío y al subsecuente desarrollo de fajas plegadas y corridas durante el Neógeno, en el flanco oriental del Altiplano. La estructura de la región de Aquine sugiere que la inversión de la cuenca del intraarco del Cretácico Superior tuvo un control sustancial en el desarrollo estructural del Cenozoico de la Cordillera Occidental.

Palabras clave: Andes centrales, Estructura, Cordillera occidental, Altiplano occidental, Depósitos sintectónicos, Edades U-Pb.

\section{Introduction}

In a constant attempt to unravel the evolution of Andean uplift, numerous studies have taken place along this long-lived, subduction-related, cordillerantype mountain belt (sensu Dewy and Bird, 1970), of which many have focused on the formation of the Altiplano plateau (e.g., Isacks, 1988; Allmendinger et al., 1997; Lamb et al., 1997; Gregory-Wodzicki, 2000; Elger et al., 2005; McQuarrie et al., 2005; Barnes et al., 2008; Barnes and Ehlers, 2009; Hartley and Evenstar, 2010; Jordan et al., 2010; Charrier et al., 2013; Garzione et al., 2014). Crustal thickening by horizontal shortening and associated deformation has been evoked as a prime mechanism for mountain building throughout the western margin of South America (Isacks, 1988; Allmendinger et al., 1997) and for bending of the Bolivian orocline (e.g.,
Isacks, 1988; Arriagada et al., 2008). Other factors proposed to have controlled orogeny of the Andes are magmatic addition to the lithosphere, lower-crustal ductile flow (e.g., Isacks, 1988; Allmendinger et al., 1997), lower lithosphere removal or delamination (e.g., Garzione et al., 2006, 2014), orogen-scale westward tilting (e.g., Lamb et al., 1997; Farías et al., 2005; Jordan et al., 2010), isostatic balancing of crustal deformation (e.g., Victor et al., 2004; Farías et al., 2005) and massive surface erosion (e.g., Montgomery et al., 2001).

The structural evolution of the morphostructures east of the Altiplano have been intensively studied (Fig. 1a) and shows the following sequence: deformation and initial block exhumation migrated eastwards through the Eastern Cordillera during the Eocene and early Oligocene (ca. 40-30 Ma), across the Interandean Zone during the late Oligocene- 

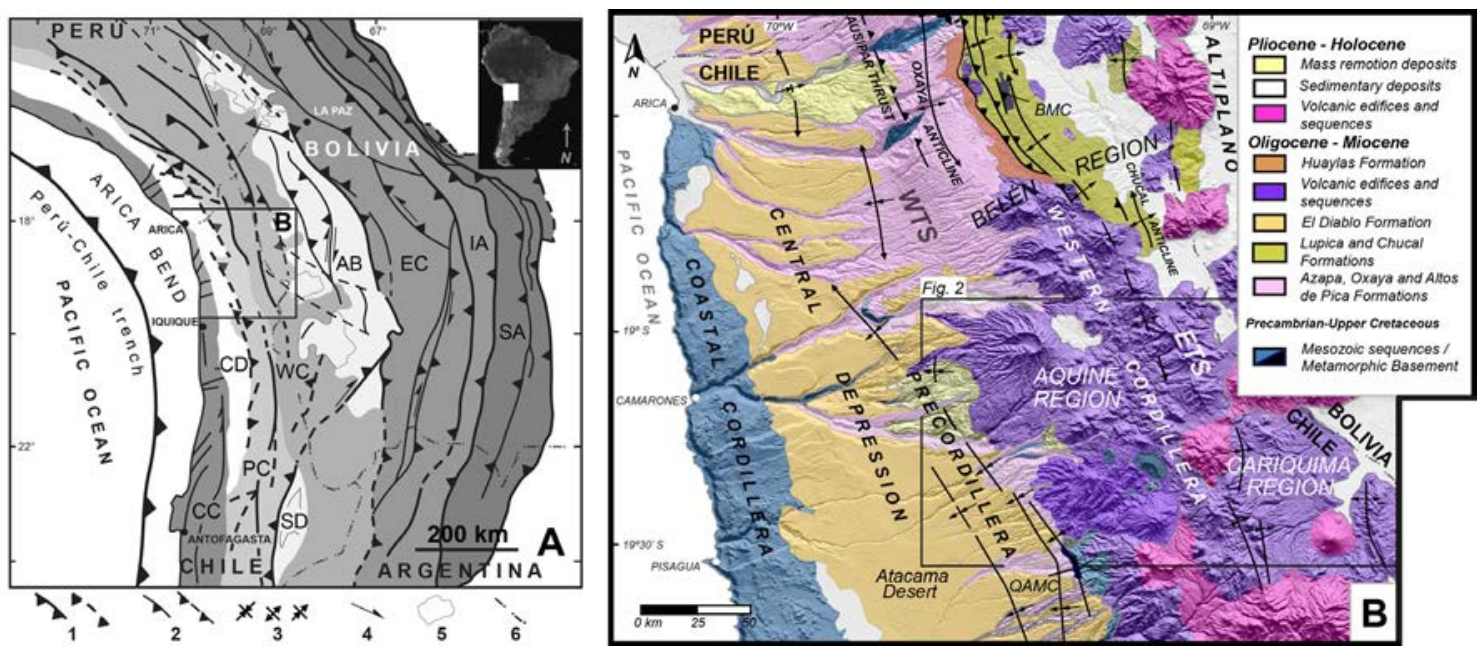

FIG. 1. A. Physiography of the Central Andes and thrust systems that define the limits of labeled morphostructural provinces. The Interandean Zone is included as part of the eastern margin of the Eastern Cordillera. SA: Subandean ranges; IA: Interandean ranges; EC: Eastern Cordillera; AB: Altiplano Basin; WC: Western Cordillera; PC: Precordillera; CD: Central Depression; CC: Coastal Cordillera; SD: Salars Depression; (Modified from Charrier et al., 2013); B. Simplified geological map of northernmost Chile ( 18 $8^{\circ} 30^{\prime}-19^{\circ} 30^{\prime}$ S) (Modified from García et al., 2004, 2011; Charrier et al., 2007, 2013; Cortés et al., 2012a). BMC: Belén Metamorphic Complex; QAMC: Quebrada Aroma Metaturbiditic Complex; WTS: West Vergent Thrust System; ETS: East Vergent Thrust System. Simbology: 1. Major thrusts; 2. Secondary faults and structural alignments; 3. Syncline, anticline and monocline axis; 4 . Strike-slip direction of displacement; 5. Major lakes and salars; $\mathbf{6}$. International border.

Miocene (ca. 25-18 Ma), and into the Subandean Sierras during most of the Neogene (ca. 20-0 Ma) (McQuarrie et al., 2005; Barnes et al., 2012), by means of thick- and thin-skinned, mainly east-vergent, but also doubly-vergent, fold-and-thrust systems.

In contrast, the structural geology of the western border of the Altiplano in Chile, adjacent to Bolivia and northwestern Argentina (Fig. 1), is obscured by widespread Neogene volcanic products of the Andean Central Volcanic Zone, limiting our access and understanding of the Mesozoic, Paleogene and even Neogene Andean structural history in this area. Within this sector, the geology of the Western Cordillera and Precordillera indicates a complex history of long-lived compressive tectonics, which includes middle Eocene deformation (Incaic compressive phase) (e.g., Steinmann, 1929; Cornejo et al., 2003; Charrier et al., 2007; 2009), which has been correlated with a significant increase in the velocity of plate convergence during this epoch (Pardo-Casas and Molnar, 1987), and possibly an Early to Late Cretaceous compressive event (Peruvian phase, e.g., Steinmann, 1929; Jaillard, 1992; Bascuñán et $a l ., 2015)$ and a Late Cretaceous-early Cenozoic compressive event (K-T phase; Cornejo et al., 2003; Charrier et al., 2007, 2009, 2013).

During the Neogene, the Western Cordillera and its magmatic arc (Fig. 1) developed continuously under a compressive tectonic regime since the late Oligocene-early Miocene, beginning with the Quechua phase of Mégard (1984), which is correlated with another major increase in the velocity of plate convergence at ca. 30-20 Ma (Pardo-Casas and Molnar, 1987; Somoza, 1998). Since this time, two deeply-rooted, orogen-scale thrust systems, with opposite vergences and NNW-SSE to N-S trends, developed aligned and along both the Western Cordillera and Precordillera (Charrier et al., 2013) (Fig. 2), with the West-Vergent Thrust System (WTS) located within the Precordillera (Muñoz and Charrier, 1996; Victor et al., 2004; Farías et al., 2005; García and Hérail, 2005; García et al., 2011) and the East-Vergent Thrust System (ETS) located within the Western Cordillera, in the presentday arc (Charrier et al., 2005; Farías et al., 2005; Cortés et al., 2012a). These systems controlled the Neogene structural and depositional evolution of this part of the Andes (Charrier et al., 2007, 2013; 


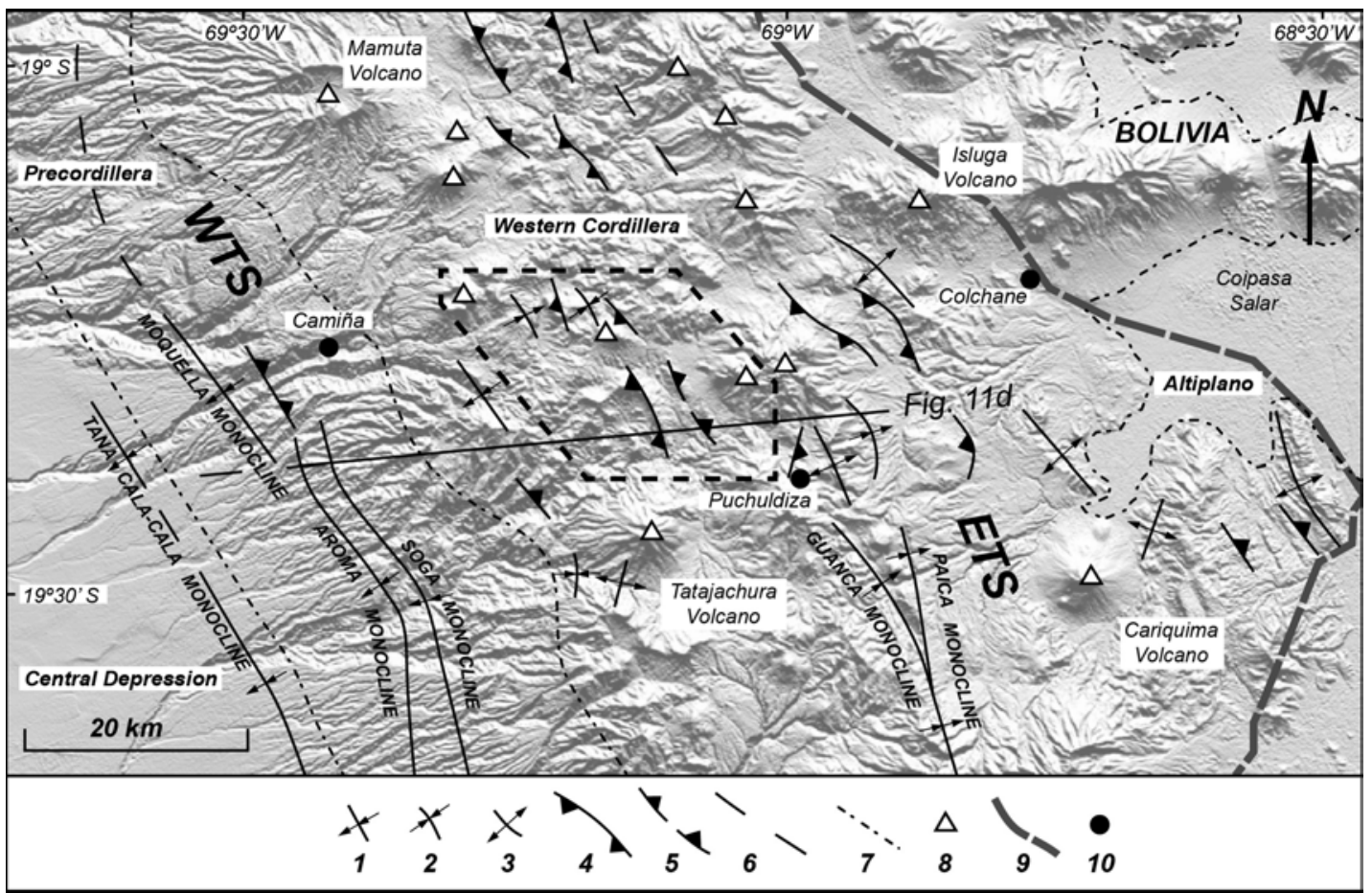

FIG. 2. STRM DEM based shaded relief image for the Western Cordillera, and adjacent Precordillera and Altiplano. Main structures are taken from Pinto et al. (2004), Farías et al. (2005), Cortés et al. (2012a,b), García et al. (2013), Herrera et al. (2013), Cortés et al. (2014), Valenzuela et al. (2014), and this study. WTS: West Vergent Thrust System; ETS: East Vergent Thrust System. Simbology: 1. Monocline; 2. Syncline; 3. Anticline; 4. Thrust; 5. Covered thrust; 6. Inferred structure; 7. Approximate limits of Andean morphostructures; 8. Miocene to Holocene volcanic center; 9. International border; 10. Town/village. Polygon encloses the geological map for this study, shown in figure 4 and the location of the model cross section in figure 11 is indicated.

García et al., 2011), exerting a substantial role in the construction of the present-day relief of the region (Muñoz and Sepúlveda, 1992; Muñoz and Charrier, 1996; Pinto et al., 2004; Victor et al., 2004; Charrier et al., 2005; Farías et al., 2005; Jordan et al., 2010; Cortés et al., 2012a, b). Nonetheless, the detailed temporal and geometrical interrelationship of these structural systems has not yet been well established, nor the role they have played in controlling the lithostratigraphy and structure of the region lying between them. Understanding the relationship of these two structural systems is crucial for comprehending the Cenozoic structural evolution of the western border of the Altiplano.

We have focused on a region of the Western Cordillera in the Central Andes (the Aquine region; $\left.19^{\circ} 15^{\prime} \mathrm{S}-19^{\circ} 30^{\prime} \mathrm{S}\right)$ between the WTS and ETS (Fig. 2), which exhibits a narrow ( $\sim 25 \mathrm{~km})$ but elongate area in which deformed Mesozoic and Cenozoic volcanic and sedimentary rocks are well exposed. This occurrence has allowed us to carry out an integrated structural, stratigraphical and geochronological analysis of the Western Cordillera. The main objective of this contribution is to elucidate the timing and style of deformation in the Western Cordillera by integrating available and new geochronological data with detailed stratigraphy and structural mapping. Our purpose is to generate a coherent conceptual model for the Cenozoic structural and depositional evolution of the Western Cordillera in order to clarify the relationship between the WTS and ETS.

\section{Geological setting}

\subsection{General geodynamic framework}

The tectonic evolution of the western margin of South America has been described as the result of discrete events, or "phases", (e.g., Steinmann, 
1929; Mégard, 1984) of intense compressive tectonics, beginning in the Early Cretaceous, in a geodynamic environment characterized by continuous subduction since the Jurassic (Charrier et al., 2007). These compressive events include: the Early to Late Cretaceous "Peruvian" phase; the Late Cretaceous-early Cenozoic "K-T" phase; the middle Eocene "Incaic" phase; the late Oligocene-Early Miocene "Quechua" phase, and the late Miocene "Pehuenche" phase (e.g., Steinmann, 1929; Mégard, 1984; Jaillard, 1992; Gregory-Wodzicki, 2000; Cornejo et al., 2003; Arriagada et al., 2006; Hoke et al., 2007; Charrier et al., 2007, 2009, 2013; Farías et al.,2010). The phases are interpreted as a product of changing plate convergence conditions through time, and consequent deformation of the leading edge of the continental plate (Charrier et al., 2007, 2013). Specifically, the Oligocene-Miocene Quechua event has been correlated with breakup of the Farallon plate into the Nazca plate and an associated increase in the convergence rate (PardoCasas and Molnar, 1987; Somoza, 1998; Reutter, 2001). Crustal deformation during this period has been inferred to have been associated with increased ductile thickening and melting of the lower crust, with a consequent influence on late Paleogene and Neogene magmatism, and formation of structural systems along the western flank of the Altiplano during most of the Neogene (e.g., Victor et al., 2004; Farías et al., 2005).

\subsection{Geological context: physiography, lithostra- tigraphy and structure of the Central Andes}

The Central Andes, between $\sim 18^{\circ}$ and $\sim 22^{\circ} \mathrm{S}$, are marked by a series of continental scale, $\sim \mathrm{N}-\mathrm{S}$ trending, morphostructural units of a highly contrasting character. From west to east, at $\sim 19^{\circ} 30^{\prime} \mathrm{S}$, these correspond to the Coastal Cordillera, the Central Depression, the Precordillera, the Western Cordillera, and the Altiplano (Fig. 1). The abrupt west to east elevation increase $(\sim 1,000$ to $\sim 6,500 \mathrm{~m}$ a.s.l.) from the Central Depression to the Altiplano has been ascribed to the development of a wide, crustalscale monocline (Isacks, 1988), or attributed to the development of the structural systems that bound the Western Cordillera to the west (WTS) and east (ETS) (e.g., Muñoz and Sepúlveda, 1992; Muñoz and Charrier, 1996; Farías et al., 2005; Charrier et al., 2005; Jordan et al., 2010).

\subsubsection{Central Depression and Precordillera}

The Central Depression (Figs. 1 and 2) corresponds to a $25-100 \mathrm{~km}$ wide, relatively flat surface that shows a gradual eastward increase in altitude from $\sim 1,000$ to 1,600 $\mathrm{m}$ a.s.1. To the east, the Precordillera (Figs. 1 and 2) appears at the present-day Andean orogenic front as a $\sim 35 \mathrm{~km}$ wide slope that separates the Central Depression from the Western Cordillera. The major west to east topographic elevation increase $(\sim 1,600$ to $\sim 3,500 \mathrm{~m}$ a.s.1.) is herein attributed to thrust activity within the WTS (Muñoz and Charrier, 1996; Pinto et al., 2004; Victor et al., 2004; Farías et al., 2005).

The sub-surface of the Central Depression is composed of $\sim 1,100$ m of Oligocene-Holocene strata, which overlie a Mesozoic substratum (García et al., 2004, 2013; Hartley and Evenstar, 2010). Outcrops of the Paleozoic are restricted to the Precordillera at $\sim 19^{\circ} 30^{\prime} \mathrm{S}$, where the Devonian-Carboniferous Quebrada Aroma Metaturbiditic Complex is exposed (Figs. 1b and 3) (Harambour et al., 1990; Morandé et al., 2015). Mesozoic units mainly include deformed marine and continental sedimentary rocks, volcanic rocks and plutonic rocks, which underlie Cenozoic units in a regional angular unconformity, the "Choja Pediplain" of Galli (1967) (Fig. 3). Cenozoic units include conglomerates of the Azapa Formation (Oligocene), thick ignimbrite sheets of the Oxaya Formation (upper Oligocene-lower Miocene), conglomerates and ignimbrites of the Altos de Pica Formation (upper Oligocene-lower Miocene), conglomerates of the El Diablo Formation (lowerupper Miocene) and, restricted to the easternmost Central Depression, conglomerates and fine lacustrine sedimentary rocks of the Huaylas Formation (upper Miocene) (Figs. 1b and 3) (García et al., 2004; Valenzuela et al., 2014; Morandé et al., 2015). The Oxaya, Altos de Pica and El Diablo Formations exhibit westward-fanning syntectonic growth strata related to the development of the WTS (Pinto et al., 2004; Farías et al., 2005; Blanco and Tomlinson, 2013). Miocene volcanic deposits and edifices complete the Cenozoic record, covering the Precordillera from the east, of which the Mamuta (middle Miocene) and Tatajachura (upper Miocene) volcanoes are the most striking features in the region (Figs. 1, 2 and 3).

The WTS lies in the Precordillera (Figs. 1 and 2) as an almost continuous $(>450 \mathrm{~km}) \mathrm{N}-\mathrm{S}$ trending compressive structural system consisting of several west-vergent, high-angle thrusts and gentle folds with a dominantly monoclinal geometry. These structures 


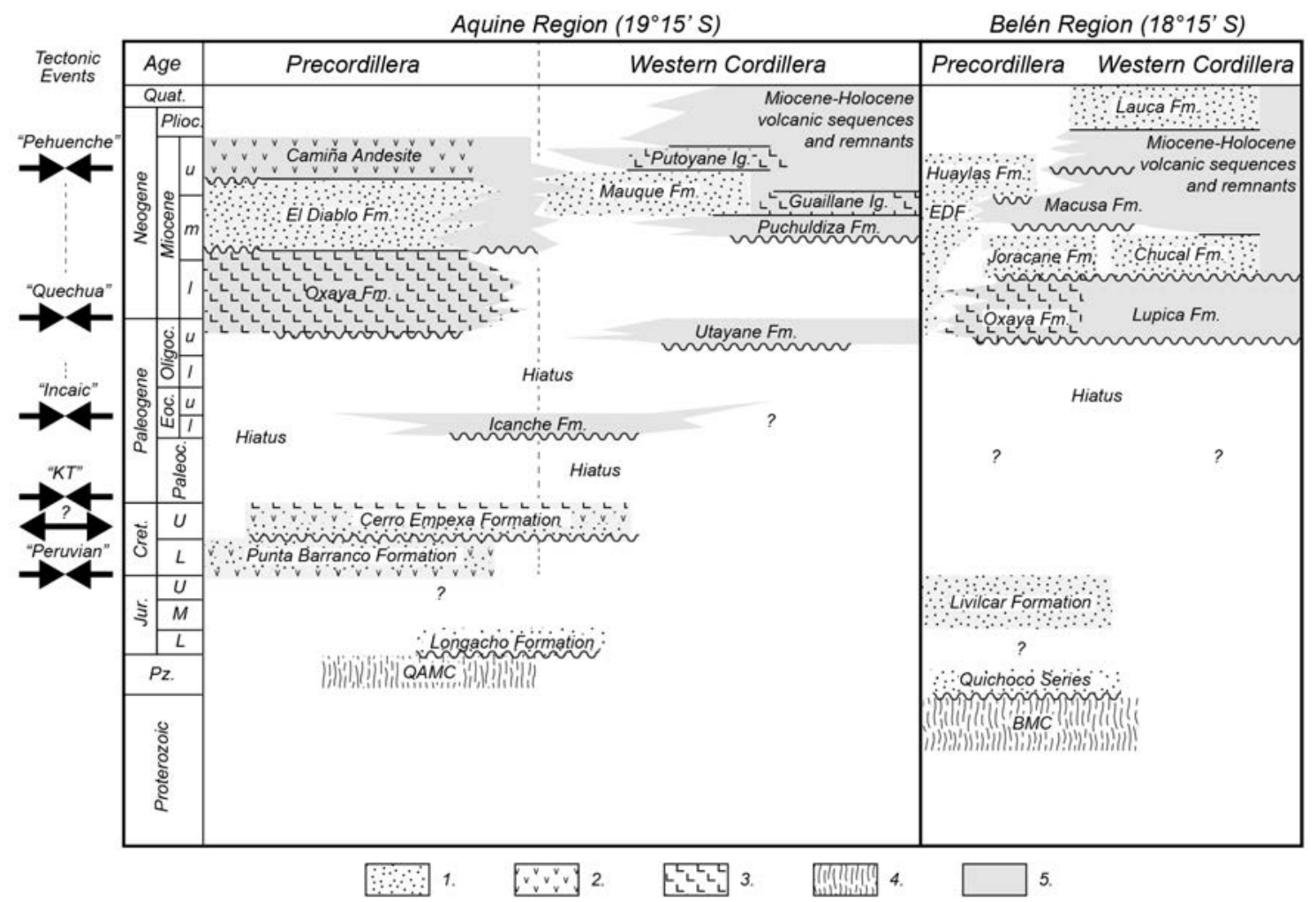

FIG. 3. Chronostratigraphic chart of the western flank of the Altiplano at the Aquine (this study) and Belén (modified from García et al., 2004) regions, showing the sequences within the Precordillera and Western Cordillera (segmented line represents the approximate limit). QAMC: Quebrada Aroma Metaturbiditic Complex; BMC: Belén Metamorphic Complex; EDF: El Diablo Formation. Andean tectonic regimes and their inferred duration are indicated: Cretaceous "Peruvian" phase; Cretaceous extensional phase; Cretaceous-Paleogene boundary "K-T" phase; Middle Eocene "Incaic" phase and Oligo-Miocene "Quechua" phase. Simbology: 1. Sedimentary rocks; 2. Andesitic lava sequences; 3. Rhyolitic lithic ignimbrites; 4. Metamorphic rocks; 5. Ignimbrites and andesitic lava sequences.

present slight variations in displacement magnitudes along-strike (e.g., Pinto et al., 2004; Farías et al., 2005), and are exposed from southern Perú $\left(\sim 18^{\circ} \mathrm{S}\right)$ to the Altos de Pica region $\left(20^{\circ}-21^{\circ} \mathrm{S}\right)$, in northern Chile (Fig. 1; García et al., 2004, 2013; Blanco and Tomlinson, 2013; Valenzuela et al., 2014; Morandé et al., 2015; Tomlinson et al., 2015). It is considered to have accommodated major deformation and consequent uplift $(>3,000 \mathrm{~m})$ in the Andean forearc and arc during the latest Oligocene-latest Miocene, and to have strongly influenced the middle to late Cenozoic paleogeographic evolution of the area (Muñoz and Charrier, 1996; García, 2002; García et al., 2004; Pinto et al., 2004; Victor et al., 2004; Farías et al., 2005; Charrier et al., 2007, 2013). The high-angle geometry of thrusts of the system in the Belén region (e.g., Ausipar fault of García et al., 2004) suggests that these correspond to re-activated normal faults (Charrier et al., 2013). In the Altos de Pica region $\left(20^{\circ}-21^{\circ} \mathrm{S}\right)$, high-angle thrusts are interpreted to be deeply rooted and linked to a regional-scale transpressive fault zone (Victor et al., 2004), the Precordilleran Fault System (PFS) (Scheuber and Reutter, 1992; Tomlinson and Blanco, 1997).

\subsubsection{Western Cordillera and Altiplano}

The Western Cordillera (Figs. 1 and 2) represents the present-day volcanic arc. With an irregular topography that varies between $\sim 3,700$ and 4,700 $\mathrm{m}$ a.s.l., it is also characterized by high peaks that surpass 5,300 $\mathrm{m}$ a.s.1., which correspond to late Neogene and Quaternary volcanoes (e.g., Isluga and Cariquima volcanoes; Fig. 2). Towards the Altiplano, the topography rapidly decreases and 
becomes relatively smooth, with a mean elevation of $\sim 3,700 \mathrm{~m}$ a.s.l. (Horton et al., 2001).

At $18^{\circ}-19^{\circ} \mathrm{S}$, the stratigraphy along the Western Cordillera and adjacent Altiplano is mostly composed of Cenozoic deposits (Figs. 1b and 3). In spite of the latter, thrusting of the easternmost features of the WTS has exposed schists and gneisses of the upper Proterozoic-lower Paleozoic Belén Metamorphic Complex (BMC in figures $1 \mathrm{~b}$ and 3) (Pacci et al., 1980; Basei et al., 1996; Bahlburg and Hervé, 1997; García, 1996, 2002; García et al., 2004; Loewy et al., 2004). The majority of the record involves Cenozoic sedimentary and volcanic deposits of the Lupica (upper Oligocene-lower Miocene), Chucal (lowermiddle Miocene), Macusa (middle-upper Miocene) and Lauca (Pliocene-Pleistocene) Formations, which are covered by volcanic units of the latest Neogene (Miocene to Holocene) (Figs. 1b and 3) (Riquelme, 1998; García, 2002; García et al., 2004; Charrier et al., 2005). At $\sim 19^{\circ} 15^{\prime} \mathrm{S}$, Cretaceous rocks have been thrust over a series of late Oligocene to Pleistocene sedimentary and volcanic layers that represent correlatives to the units in the Belén area mentioned above (Cortés et al., 2012a, b, 2014; Herrera et al., 2013; Valenzuela et al., 2014). Within Neogene deposits, syntectonic eastward-fanning growth strata and progressive unconformities have been registered in the Chucal anticline $\left(\sim 18^{\circ} 45^{\prime} \mathrm{S}\right.$; Fig. 1b) (García et al., 2004; Charrier et al., 2005) and to the east of the study area, towards the Altiplano (Figs. 1b and 2) (Cariquima Region of Cortés et al., 2012a).

The ETS dominates the structure of the easternmost Western Cordillera (Figs. $1 \mathrm{~b}$ and 2). It is a $\sim \mathrm{N}-\mathrm{S}$ aligned, $\sim 200 \mathrm{~km}$ long $\left(18^{\circ} 40^{\prime}-19^{\circ} 40^{\prime} \mathrm{S}\right)$ system of thin- and thick-skinned thrusts and folds that share a mainly east vergence (Figs. $1 \mathrm{~b}$ and 2). The system is considered active since the early Miocene until the early Pliocene, as a coeval counterpart of the WTS (Charrier et al., 2005; Farías et al., 2005; Cortés et al., 2012a) and responsible for the origin of eastward-fanning growth strata in Miocene units. At $\sim 19^{\circ} 30^{\prime} \mathrm{S}$ (Cariquima Region) the system it is thought to be mainly controlled by two deeply-rooted, substratum-involving thrusts, with detachment levels that reach $\sim 20 \mathrm{~km}$ depth in the Altiplano Low Velocity Zone (ALVZ) (ANCORP, 2003; Cortés et al., 2012a). The surface expression of the westernmost of these two thrusts is represented by the Guanca monocline located just to the southeast of the Aquine area (Fig. 2).

\section{Geology of the Aquine region}

\subsection{Stratigraphy}

The lithostratigraphy of the Aquine region consists of a Mesozoic substratum composed of Upper Cretaceous volcanic and sedimentary rocks, and a Cenozoic cover consisting of late Oligocene-early Miocene ignimbrites and Neogene sedimentary and volcanic deposits. Geochronological data for the study region is summarized in table 1 and detailed in section 3.2 U-Pb geochronology. The general stratigraphy of the region and correlative units north of the study area are summarized in figure 3 .

\subsubsection{Mesozoic Substratum}

The substratum of the Cenozoic in the region is represented by the Upper Cretaceous Cerro Empexa Formation, which is exposed along the southwestern portion of the study area (Fig. 4). The Cerro Empexa Formation corresponds to a volcanic and sedimentary unit, first defined by Galli and Dingman (1962) and extensively exposed along the Precordillera of northern Chile, from $\sim 19^{\circ} \mathrm{S}$ to $21^{\circ} \mathrm{S}$ (Blanco and Tomlinson, 2013; Valenzuela et al., 2014; Morandé et al., 2015; Tomlinson et al., 2015). In the Precordillera, the lower portions of the unit are composed of andesitic lavas, including auto-breccias, overlain by conglomerates and conglomeratic sandstones. The upper portion is mainly composed of poorly sorted sandstones. In the Aquine region, the Cerro Empexa Formation reaches a thickness of $\sim 1,000 \mathrm{~m}$, it is folded and underlies Oligocene and Miocene units in angular unconformity. Eastwards, in the Western Cordillera, the unit shows a predominance of lithic and welded tuffs and subordinate andesites, dacites and sandstones, reaching a thickness of $>500 \mathrm{~m}$. The Cerro Empexa Formation underlies the sub-horizontal Icanche Formation (Fig. 4) in angular unconformity along the western portion of the Aquine region, with a gentle dip of $\sim 15^{\circ} \mathrm{W}-\mathrm{NW}$. Towards the east, along the Putoyane valley, it underlies the Puchuldiza and Mauque formations, upper Miocene andesitic lavas (Fig. 4), and it is thrusted over the Icanche Formation. In the Aroma valley, the Cerro Empexa Formation underlies in strong angular unconformity the Icanche Formation, the upper Miocene andesitic lavas and the Guaillane Ignimbrite (Fig. 4), and it is also thrusted eastwards over the Icanche Formation (Fig. 4). A distal fluvial 
TABLE 1. ROCK AGE DATA FOR THE AQUINE REGION.

\begin{tabular}{|c|c|c|c|c|c|c|c|}
\hline \multirow{3}{*}{ Sample } & \multirow{3}{*}{ Unit } & \multirow{2}{*}{\multicolumn{2}{|c|}{$\begin{array}{c}\text { Location } \\
\text { (UTM/WGS84) }\end{array}$}} & \multirow{3}{*}{ Method } & \multirow{3}{*}{ Sample lithology } & \multirow{3}{*}{$\begin{array}{l}\text { Age } \\
\text { (Ma) }\end{array}$} & \multirow{3}{*}{ Reference } \\
\hline & & & & & & & \\
\hline & & $\mathbf{N}$ & $\mathbf{E}$ & & & & \\
\hline $\mathrm{CS} 2-4$ & $\begin{array}{l}\text { Cerro Empexa } \\
\text { Formation-CEF }\end{array}$ & 7.865 .337 & 476.728 & $\begin{array}{l}\text { U-Pb LA-ICP-MS } \\
\text { (zircon) }\end{array}$ & $\begin{array}{l}\text { Biotite-bearing } \\
\text { dacite }\end{array}$ & $68.5 \pm 0.5$ & this study \\
\hline HC-07 & $\begin{array}{l}\text { Icanche } \\
\text { Formation-IF }\end{array}$ & 7.854 .989 & 490.455 & $\begin{array}{l}\text { U-Pb LA-ICP-MS } \\
\text { (zircon) }\end{array}$ & $\begin{array}{l}\text { Andesitic lithic } \\
\text { lapilli tuff }\end{array}$ & $49.6 \pm 0.5$ & this study \\
\hline $\mathrm{CS} 3$ & $\begin{array}{l}\text { Utayane } \\
\text { Formation-UF }\end{array}$ & 7.861 .744 & 488.572 & $\begin{array}{l}\text { U-Pb LA-ICP-MS } \\
\text { (zircon) }\end{array}$ & $\begin{array}{l}\text { Rhyolitic crystal } \\
\text { tuff }\end{array}$ & $26.7 \pm 0.3$ & this study \\
\hline GPM-84 & $\begin{array}{l}\text { Puchuldiza } \\
\text { Formation-PF2 }\end{array}$ & 7.855 .620 & 499.679 & K-Ar (whole rock) & $\begin{array}{l}\text { Welded glassy } \\
\text { ash tuff }\end{array}$ & $14.2 \pm 0.5$ & Ortiz et al., 2008 \\
\hline CS2-35 & $\begin{array}{l}\text { Guaillane } \\
\text { Ignimbrite-GI }\end{array}$ & 7.854 .319 & 492.071 & $\begin{array}{l}\text { U-Pb LA-ICP-MS } \\
\text { (zircon) }\end{array}$ & $\begin{array}{l}\text { Andesitic glassy } \\
\text { ash tuff }\end{array}$ & $13.9 \pm 1.3$ & this study \\
\hline CS2-37 & $\begin{array}{l}\text { Guaillane } \\
\text { Ignimbrite-GI }\end{array}$ & 7.851 .780 & 490.316 & $\begin{array}{l}\text { U-Pb LA-ICP-MS } \\
\text { (zircon) }\end{array}$ & $\begin{array}{l}\text { Rhyolitic crystal } \\
\text { tuff }\end{array}$ & $13.7 \pm 0.3$ & $\begin{array}{l}\text { Valenzuela et al., } \\
2014\end{array}$ \\
\hline CS2-21 & $\begin{array}{l}\text { Mauque } \\
\text { Formation-MF }\end{array}$ & 7.867 .924 & 483.769 & $\begin{array}{l}\text { U-Pb LA-ICP-MS } \\
\text { (detrital zircon) }\end{array}$ & Lithic sandstone & $11.4 \pm 0.3$ & $\begin{array}{l}\text { Valenzuela et al., } \\
2014\end{array}$ \\
\hline $\mathrm{CP} 1-5$ & $\begin{array}{l}\text { Mauque } \\
\text { Formation-MF }\end{array}$ & 7.872 .834 & 479.160 & $\begin{array}{l}\text { U-Pb LA-ICP-MS } \\
\text { (detrital zircon) }\end{array}$ & Lithic sandstone & $9.7 \pm 0.2$ & $\begin{array}{l}\text { Valenzuela et al., } \\
2014\end{array}$ \\
\hline CP1-3 & $\begin{array}{l}\text { Upper Miocene } \\
\text { andesitic lavas- } \\
\text { MVS }\end{array}$ & 7.872 .734 & 479.356 & $\begin{array}{l}\text { U-Pb LA-ICP-MS } \\
\text { (zircon) }\end{array}$ & Andesite & $8.7 \pm 0.2$ & $\begin{array}{l}\text { Valenzuela et al., } \\
2014\end{array}$ \\
\hline CP1-26 & $\begin{array}{l}\text { Upper Miocene } \\
\text { andesitic lavas- } \\
\text { MVS }\end{array}$ & 7.874 .081 & 488.013 & $\begin{array}{l}\text { U-Pb LA-ICP-MS } \\
\text { (zircon) }\end{array}$ & Andesite & $7.7 \pm 0.6$ & $\begin{array}{l}\text { Valenzuela et al., } \\
2014\end{array}$ \\
\hline M-1 & $\begin{array}{l}\text { Putoyane } \\
\text { Ignimbrite-PI }\end{array}$ & 7.863 .994 & 489.335 & K-Ar (biotite) & $\begin{array}{l}\text { Andesitic crystal } \\
\text { tuff }\end{array}$ & $6.9 \pm 0.3$ & Argandoña, 1984 \\
\hline
\end{tabular}

environment, accompanied by extrusive andesitic volcanism, is proposed for the origin of the succession in the Precordillera (Valenzuela et al., 2014). In the Western Cordillera, explosive volcanism and low-energy sedimentation within restricted intramontane basins dominate this portion of the Cerro Empexa Formation (Argandoña, 1984; Valenzuela et al., 2014). The Cerro Empexa Formation has been interpreted as the result of Upper Cretaceous arc magmatism, and coeval sedimentation, in a complex paleogeographic configuration characterized by intra-arc extension (Blanco and Tomlinson, 2013; García et al., 2013; Morandé et al., 2015; Valenzuela et al., 2014; Tomlinson et al., 2015). Radiometric analyses constrain this unit to the Upper Cretaceous, between $79.4 \pm 1.1 \mathrm{Ma}$ and $65.7 \pm 1.4 \mathrm{Ma}$ (Zircon U-Pb ages; Tomlinson et al., 2015) (ca. 79-66 Ma; Campanian-Maastrichtian). Additionally, a biotite dacite yielded an age of $68.5 \pm 0.5 \mathrm{Ma}$ (Zircon $\mathrm{U}-\mathrm{Pb}$ ages; this study) (Fig. 5a; Table 1), which also dates the unit to the Campanian-Maastrichtian $(c a .67 \mathrm{Ma})$.

\subsubsection{Cenozoic cover}

The Cenozoic is represented by middle Eocene to Pleistocene sedimentary and volcanic deposits (Figs. 3 and 4). Throughout the central and western segment of the study area, they cover the folded Cerro Empexa Formation. Collectively, Neogene deposits of the Aquine region register the depositional evolution of the middle to upper Miocene intra-arc, mainly represented by ignimbrite sheets, andesitic lavas, and subordinate sedimentary successions.

Lower Eocene deposits are composed of a succession of dacitic to rhyodacitic lithic tuffs of the Icanche Formation (Maksaev, 1978) (Fig. 4). The inferred thickness of the formation in the study area is estimated at $\sim 1000 \mathrm{~m}$ (Valenzuela et al., 2014). Tuffs within the unit, exposed along the Putoyane 


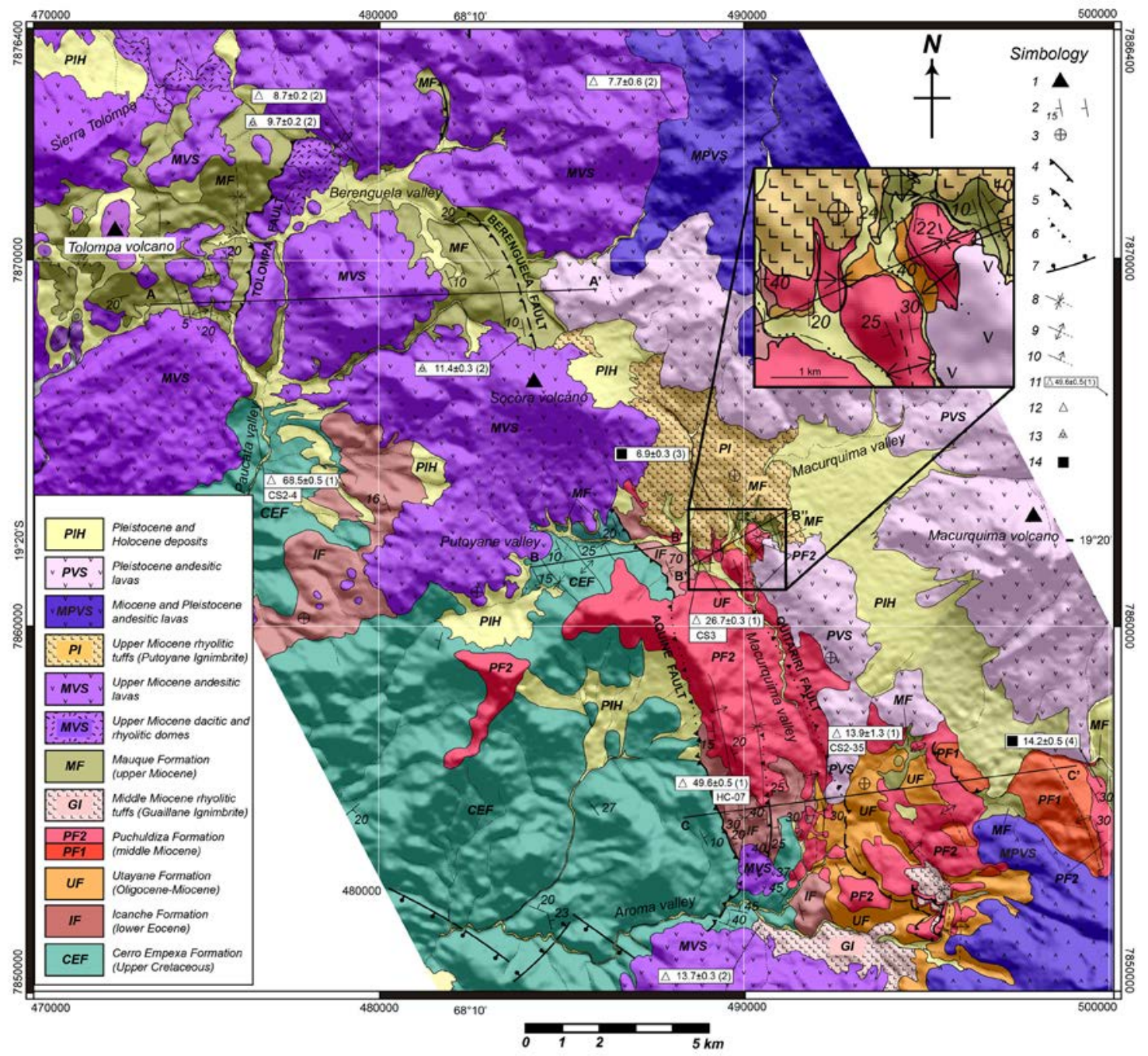

FIG. 4. Detailed geological map of the Aquine region, Western Cordillera $\left(\sim 19^{\circ} 20^{\prime} \mathrm{S}\right)$, showing main structural features described in this study (modified from Argandoña, 1984 and Valenzuela et al., 2014). A-A', B-B' and C-C' correspond to structural sections in figure 6. Simbology: 1. Volcanic center remnant; 2. Bedding; 3. Horizontal strata; 4. Observed thrust; 5. Photo-interpreted thrust; 6. Covered thrust; 7. Observed normal fault; 8. Observed/inferred syncline; 9. Observed/inferred anticline; 10. Observed/ inferred monocline; 11. Radiometric age; 12. U-Pb zircon age; 13. Detrital U-Pb zircon age; 14. K-Ar biotite age. Source for radiometric ages: this work, Valenzuela et al. (2014), Argandoña (1984) and Ortiz et al. (2008).

and Macurquima valleys, are rich in plagioclase and quartz and bear subordinate amphibole crystals, as well as pumice, contained in an ash-predominant matrix. The lithics correspond to fragments of reddish and altered andesites. In the Western Cordillera, this unit shows a moderate imprint of propylitic alteration, and it is sub-horizontal in the western portion of the study area along the Paucata valley. Towards the east, it becomes strongly folded, overlying the Cerro Empexa Formation with a strong angular discordance, which is exposed in the Putoyane and Aroma valleys (Figs. 4 and 6a). Along the Macurquima valley, the Icanche Formation is overlain in a strong angular unconformity by tuffs of the Utayane Formation and middle Miocene lavas of the Puchuldiza Formation (Fig. 4). In the Aroma valley it is also overlain in 
A) Sample CS2-4 (biotite dacite) - Cerro Empexa Formation

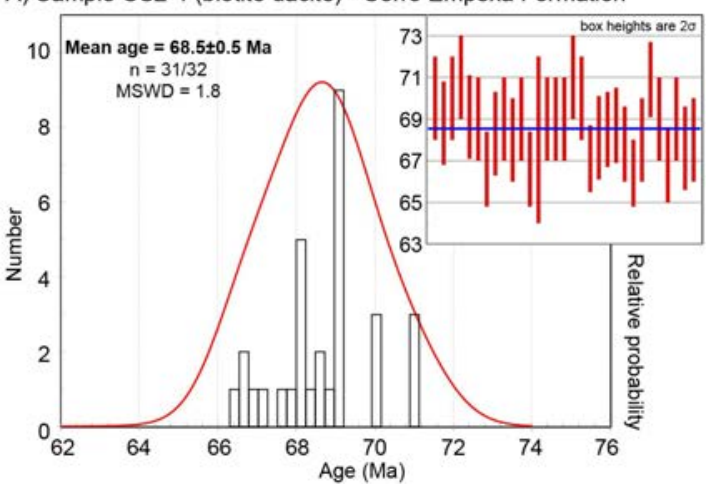

C) Sample CS-3 (crystal tuff) - Utayane Formation

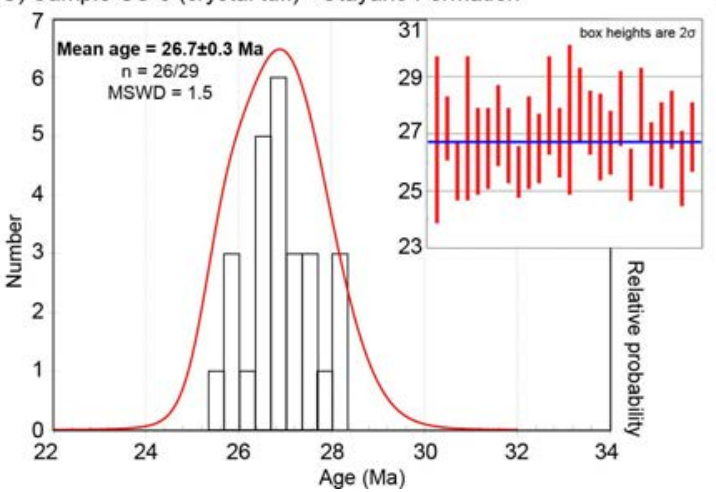

B) Sample HC-07 (lithic tuff) - Icanche Formation

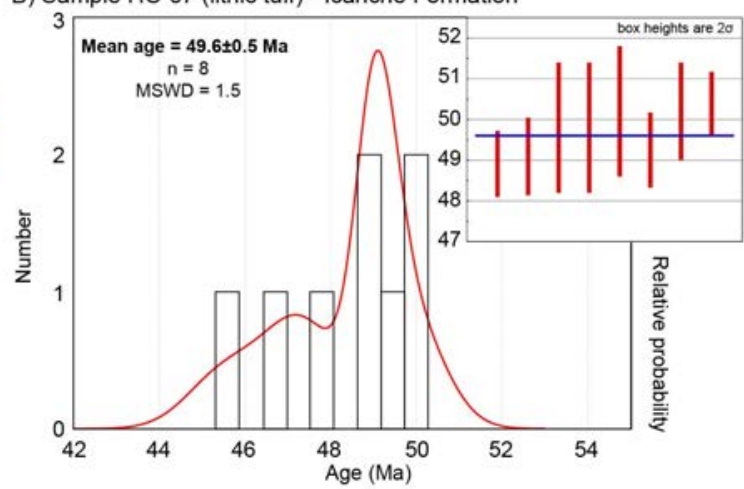

D) Sample CS2-35 (glassy ash tuff) - Puchuldiza Formation

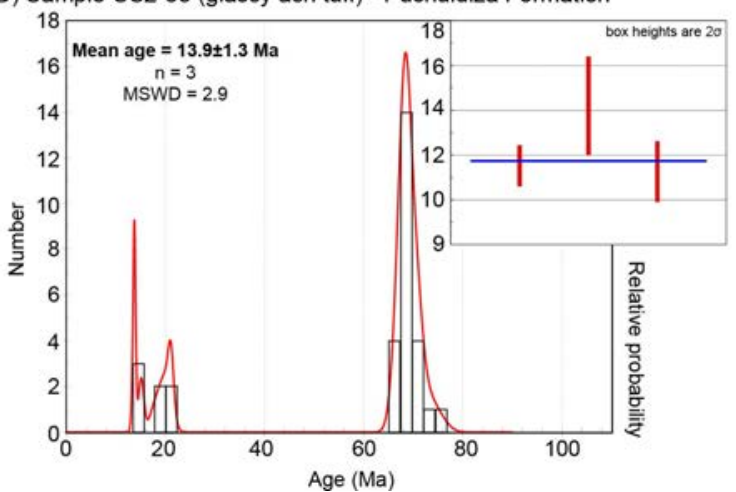

FIG. 5. Geochronological results. U-Pb zircon ages for the: A. Cerro Empexa; B. Icanche; C. Utayane; and D. Puchuldiza Formations. The background diagram in each case corresponds to relative probability diagrams (age distributions) and the overlain inset diagram is the weighted mean with error bars for the populations of representative ages of each sample. Sample locations shown in figure 4.

angular unconformity by the Guaillane Ignimbrite (Fig. 4). A lithic tuff yielded an age of $49.6 \pm 0.5 \mathrm{Ma}$ (Zircon U-Pb ages; this study) (Fig. 5b; Table 1), which dates the unit to the lower Eocene (ca. $49 \mathrm{Ma}$; Ypresian). This pyroclastic succession represents the scarcely exposed products of the Paleocene-middle Eocene magmatic arc of the N-S trending "Incaic range"; which featured as the primary topographic high during that epoch (Charrier et al., 2009, 2013).

The upper Oligocene to lower Miocene Utayane Formation (Lahsen, $1973^{1}$; Fig. 4) is composed of volcanic and sedimentary deposits, covering in strong angular unconformity the Icanche Formation along the Putoyane valley, and underlying paraconformably or with gentle angular unconformity the Puchuldiza Formation along the Putoyane and Aroma valleys (Fig. 4). This formation consists of a $\sim 200 \mathrm{~m}$ thick succession of strongly welded, lithic lapilli rhyolitic tuffs, with abundant plagioclase, biotite and quartz crystals, which are interbedded with lithic sandstones and conglomerates. In the Aquine region, it is restricted to the Macurquima valley and the southeastern portion of the Aquine region (Fig. 4). Six U-Pb zircon ages of $26.0 \pm 0.4 \mathrm{Ma}$ to $19.3 \pm 0.3 \mathrm{Ma}$ were reported by Cortés et al. (2014), in addition to a zircon U-Pb age of 26.7 $\pm 0.3 \mathrm{Ma}$ age (this study) (Fig. 5c; Table 1), allows to assign the unit to the upper Oligocene-lower Miocene (ca.27-19 Ma; Chattian-Burdigalian). The Utayane Formation represents pyroclastic flows that covered the proto-Western Cordillera and the adjacent Altiplano, in general, concomitant to the Oxaya Formation in the Precordillera and the upper Azapa Formation in the Central Depression (Figs. 1b and 3).

Covering the Cerro Empexa and Icanche Formations in angular unconformity, and the

${ }^{1}$ Lahsen, A. 1973. Geología de Puchuldiza. Informe inédito. CORFO: 49 p. Santiago. 

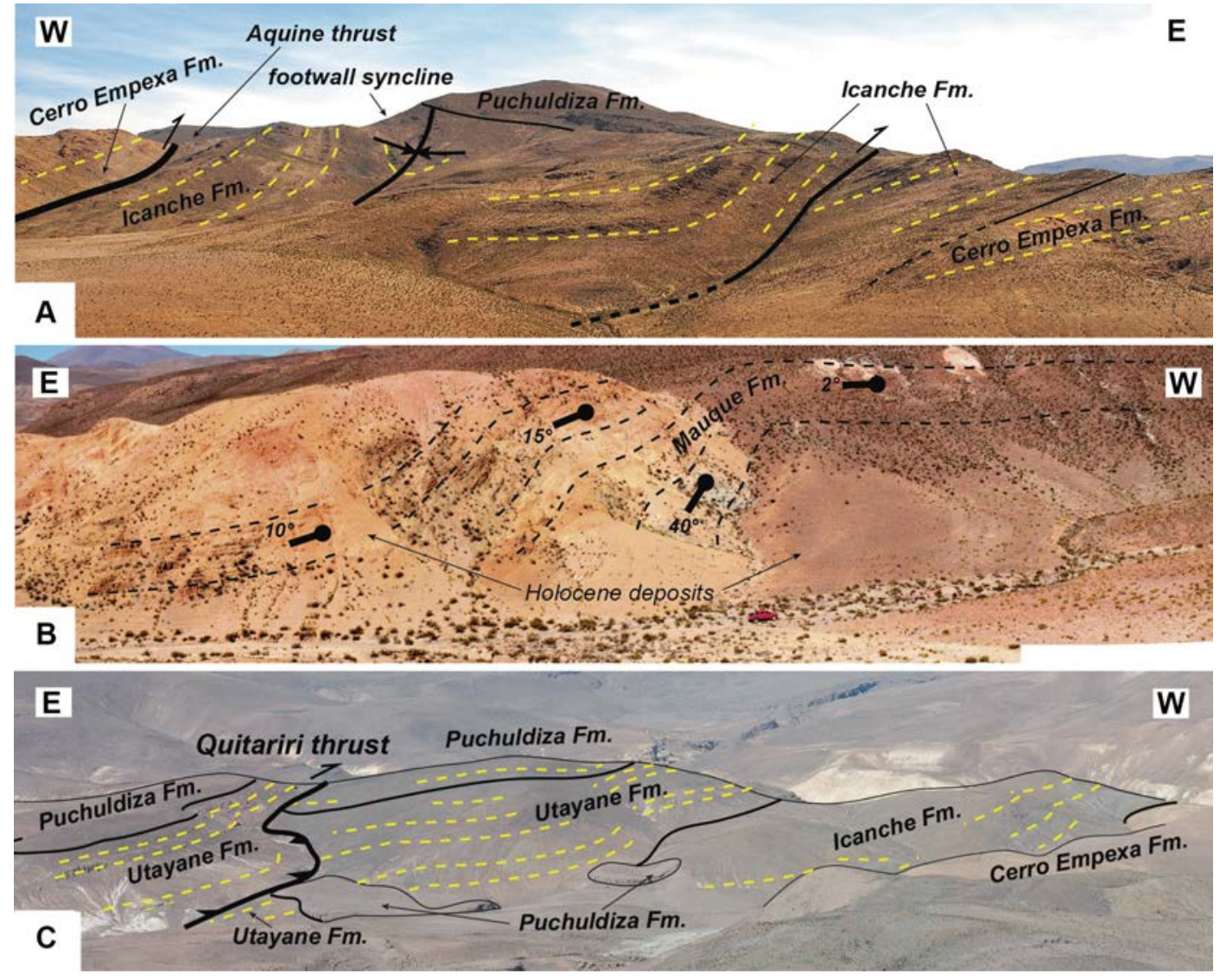

FIG. 6. Structures and deformed units of the Western Cordillera. A. A view looking north from the Aroma valley at the Aquine thrust and footwall deformation in the westernmost segment of section CC' in figure 8; B. A view looking south at the west-vergent monoclinal fold east of the Tolompa volcano in the westernmost segment of section AA' in figure 8; C. A view looking south of the Macurquima valley, where the Quitariri thrust places the Utayane Formation over the Puchuldiza Formation, located immediately south of the central segment of section CC' in figure 8 .

Utayane Formation in gentle angular unconformity or paraconformably in the Putoyane valley, the Puchuldiza Formation (Lahsen, 1973) is composed of a $\sim 80 \mathrm{~m}$-thick volcanic sequence in which we differentiated two members (Fig. 4), exposed in the southern portion of the study area and along the Macurquima, Putoyane and Aroma valleys. The Puchuldiza Formation dips gently towards the east in the Aroma and Macurquima valleys, and eastwards it is folded and faulted. However, the unconformity with the Utayane Formation is still gentle even where the unit is most deformed. The Lower Member consists of amphibole-bearing and pyroxene-rich lavas of an andesitic to dacitic affinity
( $\sim 10 \mathrm{~m}$ thick), and to subordinated centimetric ( $\sim 80-50 \mathrm{~cm}$-thick) block-and-ash deposits with a dominantly andesitic lithic content. The Upper Member corresponds to biotite-rich rhyolitic and dacitic welded tuffs, and subordinate rhyolitic and dacitic lavas, which collectively reach a thickness of $\sim 70 \mathrm{~m}$. A $14.2 \pm 0.5 \mathrm{Ma}$ age (K-Ar on biotite) reported by Ortiz et al. (2008) ${ }^{2}$ (Fig. 4; Table 1), in addition to more recent geochronological results by Cortés et al. (2014) that yielded an $13.1 \pm 0.4 \mathrm{Ma}$ $\mathrm{U}-\mathrm{Pb}$ zircon age in the Puchuldiza area (Fig. 2), allows to assign the Puchuldiza Formation to the middle Miocene (ca. 14-13 Ma; LanghianSerravallian). In this study, U-Pb zircon radiometric

${ }^{2}$ Ortiz, M.; Achurra, L.; Cortés, R.; Fonseca, A.; Silva, C.; Vivallos, J. 2008. Estudio Geológico, Geofísico e Hidroquímico del Sector de Puchuldiza. Exploración Geológica para el fomento de la Energía Geotérmica (Informe Inédito). Servicio Nacional de Geología y Minería, 168 p., Santiago, Chile. 
analyses for a glassy dacitic ash tuff yielded an age of $13.9 \pm 1.3 \mathrm{Ma}$ (Fig. 5d) for the Upper Member, consistent with the timespan given by the two ages mentioned above.

The Guaillane Ignimbrite (Fig. 4) overlays with angular unconformity the Cerro Empexa and Icanche Formations, and the Utayane and Puchuldiza Formations in gentle angular discordance, in the southernmost portion of the study area. This ignimbrite is composed of a $\sim 190 \mathrm{~m}$-thick sequence of rhyolitic welded tuffs, which are rich in biotite, pumice, and lithic fragments. Radiometric analyses for the Guaillane Ignimbrite have yielded ages of $13.7 \pm 0.3 \mathrm{Ma}$ (U-Pb zircon ages; Valenzuela et al., 2014) and $12.7 \pm 0.1 \mathrm{Ma}$ (K-Ar on biotite; Argandoña, 1984) (Fig. 4; Table 1), allowing to assign this unit to the middle Miocene ( $c a$. 14-13 Ma; Langhian-Serravallian) and indicating, based on the geochronology, that it overlaps, in part, the depositional timespan of the Puchuldiza Formation in the Puchuldiza area.

The Mauque Formation (Cortés et al., 2014; Fig. 4), first defined as the "Mauque Series" (Lahsen, 1973), corresponds to a $\sim 200 \mathrm{~m}$-thick predominately sedimentary succession, mainly composed of sandstones, conglomerates and sedimentary breccias, in addition to tuffs in its upper portions (Lahsen, 1973; Ortiz et al., 2008; Cortés et al., 2014; Valenzuela et al., 2014; Herrera et al., 2015). The Mauque Formation exhibits strong thickness variations (Figs. 6b and 7), and an imprint of moderate to strong intermediate-argillic alteration throughout the study area. It overlies the Cerro Empexa, Utayane and Puchuldiza Formations in angular unconformity. The deposits of the Mauque Formation predominantly correspond to immature lithic sandstones that are rich in andesite and dacite fragments and show well-defined cross and planar lamination. In its lower portions, the unit is composed of massive sandstones layers, with interbeds of grainand matrix-supported breccias. The breccias within the unit show inverse-normal and normal grading. Cross-stratification in sandstones is common in metric-scale lenses and paleochannels. The middle portions of the unit show metric-scale ( $<2 \mathrm{~m}$-thick) layers of laharic breccias interbedded with lithic sandstones. At the Tolompa Volcano, this portion of the succession shows flame and slump structures, and recumbent stratification (Bobadilla, 2015; Herrera et al., 2015). Towards its upper portion, the Mauque Formation consists of fine- to medium-grained lithic

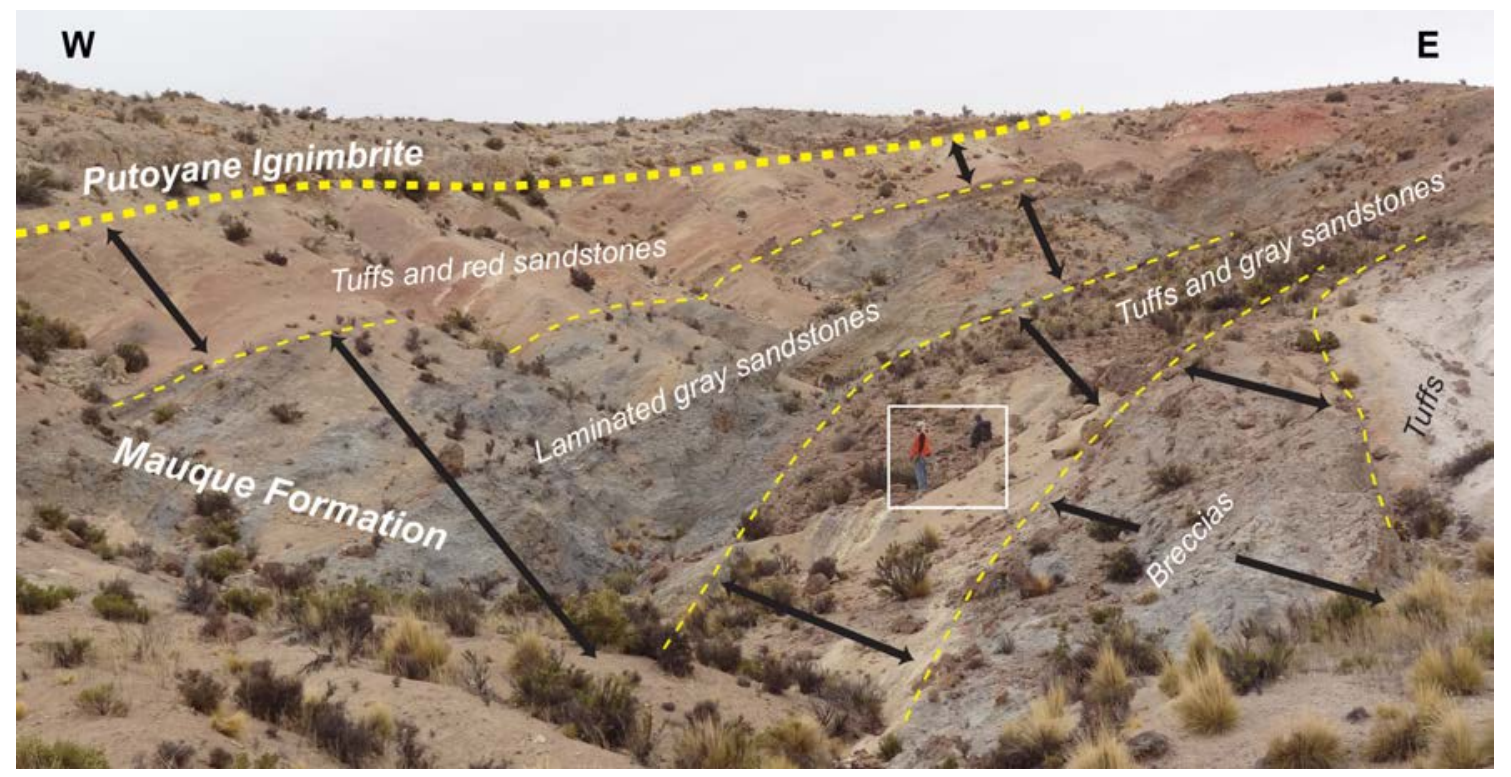

FIG. 7. A view looking north at the overturned western limb of a west-vergent anticline affecting westward-fanning metric-scale growth strata recognized within volcanic and sedimentary layers of the Mauque Formation in the Macurquima valley (Fig. 4). Note the gentle unconformity with the overlying Putoyane Ignimbrite (thick dashed line). Arrow-headed black lines are approximately perpendicular to strata bedding (fine dashed lines), highlighting thickness increases. Geologists stand as scale at the center of the image. 
sandstones that show fine parallel lamination, and coarse-grained sandstone layers interbedded with subordinate laminated conglomerates. The unit represents a depositional environment of restricted lakes in a fluvial system with coalescent debris flows within alluvial fans (Bobadilla, 2015; Herrera et al., 2015). In the northwestern portion of the study area, immediately east of the Tolompa Volcano (Fig. 4), the Mauque Formation shows a clear thickness increase from $\sim 30-40 \mathrm{~m}$ in the west to $\sim 170 \mathrm{~m}$ in the east adjacent the Tolompa fault. This trend is also observed in outcrops of the Berenguela valley where the maximum thickness occurs in the vicinity of the Berenguela fault (Bobadilla, 2015; Herrera et al., 2015). At the Putoyane valley, westward growth ( $\sim 5$ to $20 \mathrm{~m}$ of thickness increase to the west) has been registered in sandstones and breccias (Fig. 7). For the Mauque Formation, in the Berenguela Valley (Fig. 4), U-Pb detrital zircon analyses on two samples yielded maximum depositional ages for the unit of $9.7 \pm 0.2 \mathrm{Ma}$ and $11.4 \pm 0.3 \mathrm{Ma}$, which correspond to the mean age of the youngest zircon population in the samples (Table 1) (Valenzuela et al., 2014). In addition, its stratigraphic position over the Puchuldiza Formation and the geochronological data for the latter, indicate a maximum deposition age of $c a .14 \mathrm{Ma}$ for the Mauque Formation (Cortés et al., 2014; Valenzuela et al., 2014). The Mauque Formation is also overlain by the Putoyane Ignimbrite ( $c a .7 \mathrm{Ma}$; see below) in the Macurquima valley, and by $c a$. 8-7 Ma lavas in the Berenguela valley (Valenzuela et al., 2014). Hence, the total possible age range for deposition of the Mauque Formation is $c a .14-8 \mathrm{Ma}$ (middle Miocene-upper Miocene; LanghianTortonian) (Valenzuela et al., 2014). As reported by Valenzuela et al. (2014), a strong peak of 14 Ma has been identified in the U-Pb detrital zircon analyses. Moreover, according to the geochemistry and texture of lithic fragments within rocks of the unit, it has been proposed that the sediment source for the formation corresponds to the concomitant Miocene volcanic arc (Bobadilla, 2015; Herrera et al., 2015).

Volcanic sequences of the upper Miocene (Fig. 4) are composed of pyroxene-bearing andesites, dacites, basaltic andesites and subordinate lapilli tuffs, and are broadly exposed throughout the northwestern portion of the study area. Included in this unit are dacitic and rhyolitic domes. These lavas overlie in erosive unconformity the Icanche and Cerro Empexa Formations, and cover the Mauque Formation with paraconformity. Andesites and andesitic auto-breccias exposed in the southernmost portion of the study area (Fig. 4) constitute the base of the Tatajachura volcano (Fig. 2), which is assigned to the upper Miocene, based on a 6.0 \pm 1.3 Ma whole-rock K-Ar age reported by Morandé et al. (2015). Lavas from this volcano cover in angular unconformity the deformed Cerro Empexa and Icanche Formations, as well as the Guaillane Ignimbrite in the Aroma valley. Additionally, $\mathrm{U}-\mathrm{Pb}$ ages of $8.7 \pm 0.2 \mathrm{Ma}$ and $7.7 \pm 0.6 \mathrm{Ma}$ in the study area (Fig. 4; Table 1) and reported by Valenzuela et al. (2014), allows to assign all sequences of this unit to the upper Miocene ( $c$ a. 9-6 Ma; Tortonian-Messinian). The eruptive centers associated with the upper Miocene volcanic sequences correspond to volcanic edifice remnants, located at the northwestern portion of the study area (Fig. 2).

The Putoyane Ignimbrite is exposed in the Putoyane and Macurquima valleys (Fig. 4). This unit is subhorizontal, and covers the Icanche, Utayane, Puchuldiza and Mauque Formations in angular unconformity and local paraconformities along the Macurquima valley, where these older units are collectively folded (Figs. 4 and 8). It is only overlain in paraconformity by Pleistocene lavas of the Macurquima Volcano (see below) and by Pleistocene and Holocene alluvial fans, also in the Macurquima valley. Towards the west, north of the Putoyane valley, it overlies lavas of the Socora volcano in gentle angular unconformity and paraconformity (Fig. 4). This $\sim 90 \mathrm{~m}$-thick pyroclastic deposit is composed of biotite-rich, amphibole- and pyroxene-bearing crystal and lithic tuffs, of which the main lithic component is andesite rock fragments. A radiometric $\mathrm{K}-\mathrm{Ar}$ analysis on biotite for the Putoyane Ignimbrite yielded an age of $6.9 \pm 0.3 \mathrm{Ma}$ (Argandoña, 1984) (Fig. 4; Table 1), which allows to assign the unit to the upper Miocene (ca. $7 \mathrm{Ma}$; Messinian).

Associated with the remnants of NS-aligned stratovolcanoes (Figs. 2 and 4), lavas composed of amphibole-bearing andesites, interbedded with subordinate lithic tuffs, cover in paraconformity the upper Miocene volcanic sequences from the northeast (Fig. 4). Along the southeastern portion of the study area, amphibole- and biotite-bearing dacites assigned to the same unit cover the Utayane, Puchuldiza and Mauque Formations in angular unconformity, and overlie conformably the Guaillane Ignimbrite. These volcanic sequences are assigned to the upper Miocene-Pliocene (ca. 9-3 Ma; Tortonian-Piacenzian; 

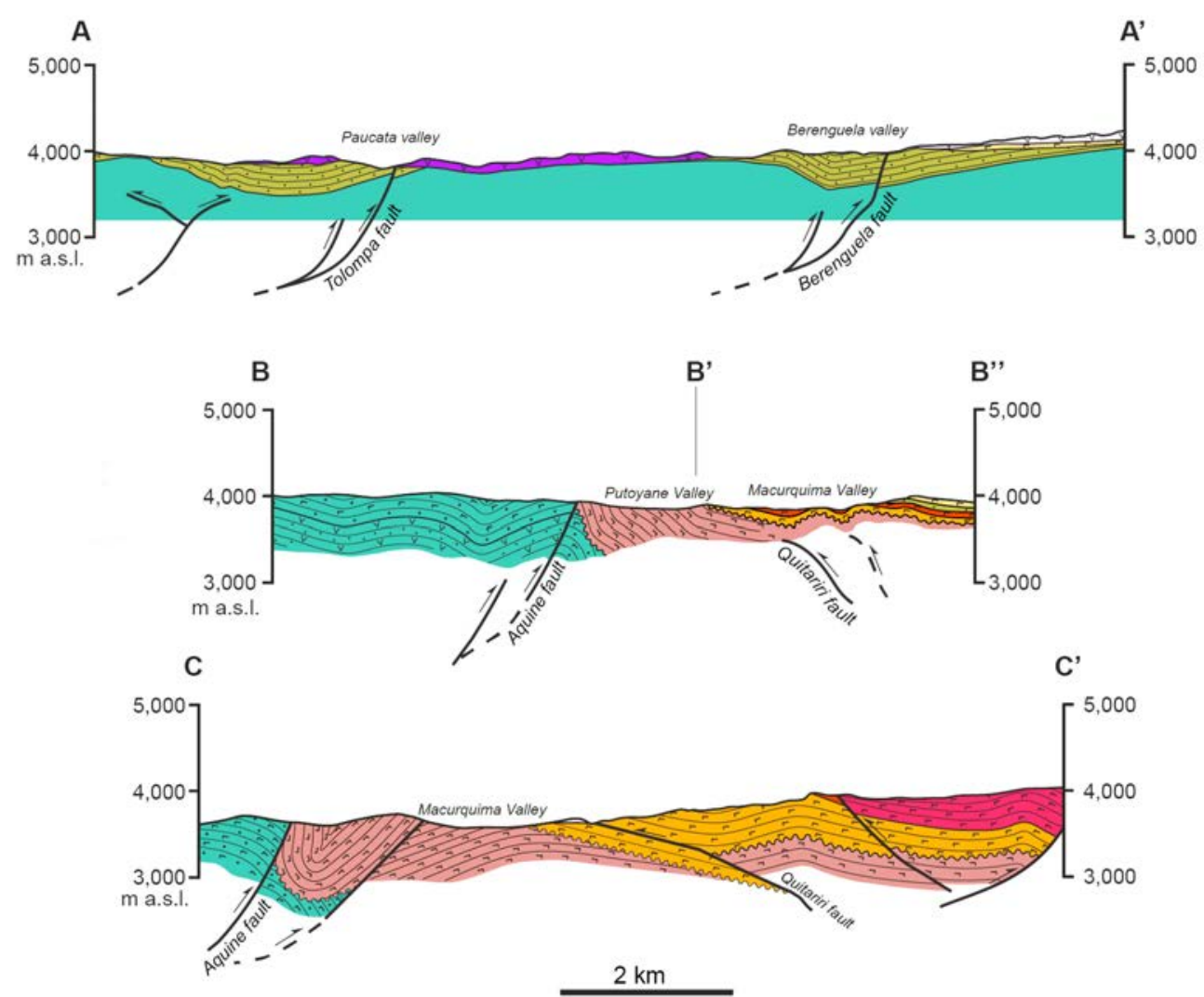

FIG. 8. Schematic structural cross-sections. AA', BB'B" and CC' correspond to the north, central and southern E-W oriented cross sections traced in figure 4 , respectively. The unit symbols are the same used in figure 4.

Ortiz et al., 2008; Cortés et al., 2014; Valenzuela et al., 2014).

The youngest volcanic unit of the Aquine region corresponds to Pleistocene volcanic sequences (Fig. 4) composed of amphibole- and pyroxene-bearing andesitic lavas that cover the upper Miocene-Pliocene volcanic sequences and the Putoyane Ignimbrite in paraconformity in the northeast part of the study area. Towards the west and south, these lavas overlie the Utayane, Puchuldiza and Mauque Formations in angular unconformity. These lavas have been assigned to the Pleistocene (ca. 2-1 Ma; Gelasian-Calabrian; Ortiz et al., 2008; Cortés et al., 2014; Valenzuela et al., 2014).

\subsection{U-Pb Geochronology}

Four rock samples from key lithologies (Table 1) have been dated through U-Pb LA-ICP-MS to more accurately time-constrain the lithostratigraphy of the study region (see Appendix for Methodology and Tables). The data of these four samples have been re-interpreted from Valenzuela et al. (2014).

Cerro Empexa. A slightly altered biotite dacite sample (CS2-4), characteristic of this formation in the central-west portion of the study area (Fig. 4), yielded an Upper Cretaceous zircon crystallization age of $68.5 \pm 0.5 \mathrm{Ma}(\mathrm{MSWD}=1.8 ; \mathrm{n}=31$ grains analyzed) (Fig. 5a). Icanche Formation. The collected lithic tuff (HC-07), crops out mainly in the central-west and -southern portions of the map area (Fig. 4). The U-Pb zircon data (35 analyzes) have a bimodal age population with peaks near 65 and $50 \mathrm{Ma}$. A single analysis of $10 \mathrm{Ma}$ probably represents a contaminant grain and therefore was rejected for the age calculation. The 65 Ma population is probably derived from the lithics in the tuff, picked up from the Cerro Empexa Formation or 
its subsurface equivalents. The 50 Ma population is interpreted to be from the magma that gave rise to the pyroclastic deposit and shows evidence for both slight inheritance and lead loss. A coherent subset of 8 out of 35 analyses gives a ${ }^{206} \mathrm{~Pb} /{ }^{238} \mathrm{U}$ weighted mean age of $49.6 \pm 0.5 \mathrm{Ma}(\mathrm{MSWD}=1.5)$ which is interpreted to be the depositional age for this formation in the early Eocene (Fig. 5b). Utayane Formation. A weighted mean ${ }^{206} \mathrm{~Pb} /{ }^{238} \mathrm{U}$ age of $26.7 \pm 0.3 \mathrm{Ma}(\mathrm{MSWD}=1.5 ; \mathrm{n}=26$ out of 29 analyses; late Oligocene) (Fig. 5c) was obtained on the crystal tuff(CS-3) belonging to this OligoceneMiocene unit from the central-southern study area (Fig. 4). Puchuldiza Formation. A U-Pb zircon age was obtained on a glassy ash tuff (CS2-35) from the central-southeastern part of the study area (Fig. 4). The U-Pb zircon data (35 analyzes) have essentially a bimodal age population with peaks near 68 and $14 \mathrm{Ma}$, and a single analysis of $485 \mathrm{Ma}$. The $485 \mathrm{Ma}$ and ca. $68 \mathrm{Ma}$ analyses are interpreted as a zircon population picked up from surrounding rocks at depth during emplacement of the glassy ash tuff. The depositional age for this unit was calculated on the three youngest zircon grains which yield an average age of $13.9 \pm 1.3 \mathrm{Ma}(\mathrm{MSWD}=2.9 ; \mathrm{n}=3$; middle Miocene). Age precision is not perfect but it can be excluded that those young ages are related to contamination during analytical work. Youngest ages in general range between 13.6 and $21.1 \mathrm{Ma}$ (Fig. 5d). Methodology for the U-Pb geochronology is detailed in the appendix.

\subsection{Structure of the Western Cordillera in the Aquine region}

Structures at the northern portion of the study area correspond to east-vergent gentle folds and thrusts (Figs. 4, 6 and 8). The Mauque Formation and volcanic sequences of the Upper Miocene are tectonically affected in this sector, and upper Miocene-Pleistocene lavas and ignimbrites postdate the faulting and folding. Towards the Sierra Tolompa (Fig. 4) from west to east, the Mauque Formation is affected by a $\sim 500 \mathrm{~m}$ wavelength, $\mathrm{N}-\mathrm{S}$ to NNW-SSE trending monocline (Figs. 6b and 8), with dips of $\sim 45^{\circ} \mathrm{E}$ to $10^{\circ} \mathrm{E}$, followed to the east by a $\sim 600$ wavelength anticline, with dips of $5^{\circ} \mathrm{W}$ and $20^{\circ} \mathrm{E}$ on its western and eastern limbs, respectively (Fig. 8). Eastwards, the Mauque Formation is thrusted over Upper Miocene lavas along the Tolompa fault, a high-angle $\left(\sim 60^{\circ} \mathrm{W}\right)$ east-vergent reverse fault, of an N-S trend. This reverse fault folds the Mauque Formation into a N-S trending syncline, immediately west of its surface trace (Figs. 4 and 8). East of the Sierra Tolompa, in the Berenguela valley, the Mauque Formation is also thrusted towards the east, over itself by means of the Berenguela fault, another high-angle reverse fault $\left(30^{\circ}-40^{\circ} \mathrm{W}\right)$, with a NNW-SSE to N-S trend. In the hanging wall of the latter, the Mauque Formation is folded into an asymmetric syncline, with dips of $30^{\circ} \mathrm{E}$ and $\sim 8^{\circ} \mathrm{W}$ in its western and eastern limb, respectively (Figs. 4 and 8 ).

In the central portion of the study area, towards the confluence of the Putoyane and Macurquima valleys (Fig. 4), along the latter, a pair of shortwavelength, NNW-SSE trending anticline and syncline are exposed (Figs. 4 and 8) and affect the Icanche, Utayane, Puchuldiza and Mauque Formations. The fold axes are spaced $<800 \mathrm{~m}$ apart, are south-plunging and asymmetrical. Growth strata are locally exposed. In particular, an anticline interpreted to be associated to the Quitariri reverse fault (Fig. 8) exhibits westward-fanning growth strata ( 5 to $20 \mathrm{~m}$ thickness increase in $200 \mathrm{~m}$ ) within sandstones, conglomerates, tuffs and breccias of the Mauque Formation (Fig. 7) along the western, limb of the anticline. Further west, the area is marked by the east-vergent, high-angle $\left(\sim 60^{\circ} \mathrm{W}\right)$ Aquine reverse fault, that places the Cerro Empexa Formation over the Icanche Formation, and is overlain by Miocene lavas of the Socora volcano (Figs. 4, $6 \mathrm{a}$ and 8). Within the hanging wall of the reverse fault, along the Putoyane valley, three NNW-SSE trending folds affect the Cerro Empexa Formation but not the unconformably overlying Puchuldiza and Mauque Formations. Wavelengths of the folds reach 1,000 to $1,500 \mathrm{~m}$, and dips throughout their limbs reach $\sim 45^{\circ} \mathrm{ENE}$ and $\sim 25^{\circ} \mathrm{WSW}$ near the core of the easternmost syncline (Fig. 8).

In the southern part of the Aquine study area, exposed along the Aroma valley (Fig. 4), a tight, north-plunging, symmetrical syncline affects the Icanche Formation in the footwall of the Aquine fault, and, as well, is thrusted in its eastern limb (Figs. 4, 6a and 8). This footwall syncline shows maximum dips of $\sim 80^{\circ} \mathrm{W}$ and $\sim 45^{\circ} \mathrm{W}$ in its western and eastern limbs, respectively. The fault plane within the east limb of the footwall syncline dips $\sim 40^{\circ} \mathrm{W}$, and its displacement is towards the east (Figs. 6a 
and 8). In between the Putoyane and Aroma valleys, the upper member of the Puchuldiza Formation overlies the Cerro Empexa and Icanche Formations and partially covers the trace of the Aquine fault (Fig. 4). East of the Aquine fault the Puchuldiza Formation is gently folded into a N-S trending open asymmetric anticline followed to the east by an open symmetric syncline, with $\sim 2 \mathrm{~km}$ wavelength (Fig. 4). Like the Aquine fault, the anticline is eastvergent. A minimum throw for the Aquine fault has been estimated at $200-300 \mathrm{~m}$, based on the topography of the erosive unconformity between the Puchuldiza Formation and Cerro Empexa and Icanche formations. Westwards, across the Aroma Valley, Argandoña (1984) reported the occurrence of NW-SE to SW-NE trending normal faults within the Cerro Empexa Formation.

The structures exposed in the southeastern portion of the Aquine study area, east of the Aquine fault (Fig. 4), are of contrasting character in that they have an opposite structural vergences forming a triangular zone. A west-vergent structure in this area is the NNW-SSE trending west-vergent Quitariri reverse fault (Figs. 4, 6c and 8). The Quitariri fault directly affects the Utayane and Puchuldiza Formations and the Guaillane Ignimbrite in the southernmost sector of the study area, and can be projected to the north, to the Macurquima valley, where it is interpreted to be a blind thrust responsible for formation of the west-vergent anticline with westward-fanning growth strata in the Mauque Formation described above (Figs. 4 and 7). At the confluence of the Aroma and Macurquima valleys, the Quitariri fault cuts the Miocene units by means of a low-angle $\left(<30^{\circ}\right.$ ENE) ramp, above which the Utayane Formation is folded into a gentle symmetrical anticline. Further east, the Lower Member of the Puchuldiza Formation is thrusted above its Upper Member by means of a higher angle ( $\left.c a .40^{\circ} \mathrm{E}\right)$ dipping fault. These structures probably involve the Icanche Formation in depth (Fig. 8). Because of the growth strata relations observed in the Macurquima valley, in the central portion of the study area, we infer that deposition of the Mauque Formation is involved in this thrust system. In the hanging wall of the easternmost thrust, a syncline-anticline fold pair is developed, affecting both members of the Puchuldiza Formation at the surface (Figs. 4 and 8). Development of the fold pair is thought to be controlled by an east-dipping ramp at depth (Fig. 8).

\section{Discussion}

Interpretation of new field and geochronologic data have allowed us to reconstruct the history of deformation and deposition within the Western Cordillera, and relate the history to the tectonic and stratigraphic evolution of the adjacent WTS and ETS in northernmost Chile ( 18 $\left.8^{\circ} 30-19^{\circ} 30^{\prime} \mathrm{S}\right)$. The structural and stratigraphic analysis allows to establish three contractional deformation episodes in the Aquine region during the Cenozoic (Figs. 9, 10 and 11), and a preceding extensional phase during the Late Cretaceous is inferred. Constraints have been established by the structural features and the relationships between lithostratigraphic units involved explained above.

\subsection{First episode (49-27 Ma)}

The Cerro Empexa Formation has been interpreted to have developed in an extensional arc setting towards the south $\left(19^{\circ} 30-21^{\circ} \mathrm{S} ;\right.$ e.g., Charrier et al., 2007, 2009; Blanco and Tomlinson, 2013; Gallardo et al., 2013; Morandé et al., 2015; Tomlinson et al., 2015), as well as the Mesozoic formations that comprise the substratum in the Precordillera towards the north $\left(18^{\circ}-19^{\circ} 30^{\prime}\right.$ S; e.g., García, 2002; García et al., 2004; Charrier et al., 2007, 2013). Normal faults described within the Cerro Empexa Formation in the southernmost portion of the Aquine region, in the hanging wall of the Aquine reverse fault, may be from this period, although a younger age cannot be excluded (Fig. 10). The high-angle character of the Cenozoic substratum-involving thrusts is unlikely to be a consequence of purely compressive tectonics (e.g., Marques and Nogueira, 2008; Bonini et al., 2012), and suggests that these structures likely correspond to reversely reactivated normal faults that participated in the development of the Jurassic and Early Cretaceous backarc basins (e.g., Charrier et al., 2007). Evidence for a postCretaceous, pre-Early Eocene deformation, before deposition of the Icanche volcanics, is given by the angular discordance between the Cerro Empexa and Icanche Formations (Figs. 9a; 11a). The folding of the Cerro Empexa Formation can be correlated to the Cretaceous-Paleogene boundary compressive event ("K-T" phase; Cornejo et al., 2003) broadly recognized in northern Chile for the latest Cretaceous and early Paleocene (e.g., Amilibia et al., 2008; 


\section{A) Early Eocene (initial state; ca. $49 \mathrm{Ma})$}
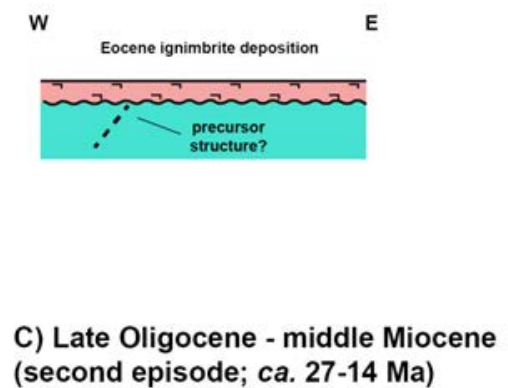

\section{B) Middle Eocene? contraction (first} episode; post-49 Ma, pre-27 Ma)

W

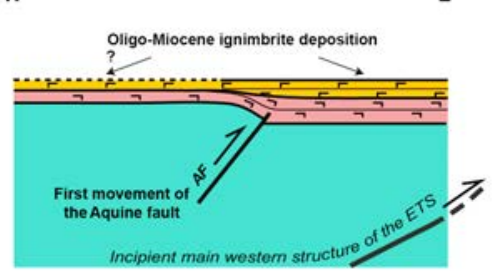

D) Middle Miocene - Pleistocene (third episode; ca. 14-6 Ma)

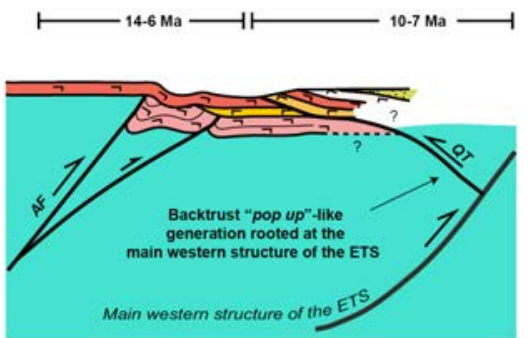

FIG. 9. Simplified structural model for development of the Aquine thrust and associated deposits in the Macurquima valley area for the A. Early Eocene; B. Middle Eocene-Upper Oligocene; C. Upper Oligocene-Middle Miocene; and D. Middle MiocenePleistocene (Present-day configuration). The east-vergent thrust in which the Quitariri fault (QT) is rooted has been traced following Cortés et al. (2012a). AF: Aquine fault; ETS: East Vergent Thrust System.

Blanco et al., 20123; Charrier et al., 2007, 2009, 2013; Martínez et al., 2013).

The deformed volcanic deposits of the Icanche Formation, also unconformably overlying Miocene Utayane Formation indicate that after explosive early Eocene volcanism (Fig. 9a), a contractional event, most likely related to the middle Eocene Incaic phase, affected this segment of the arc between $c a .49$ and $27 \mathrm{Ma}$ (Fig. 10). Deformation was accomplished by high-angle substratum-involving thrusts, including the east-vergent Aquine reverse fault (Fig. 9b). This proposed situation for the region is simplified in figure 11a. Additionally, paleocurrent and clastic provenance data for Paleogene units in the Altiplano basin indicate the formation of an uplifted area west of the basin, which has been explained in terms of the development of a fold-and-thrust belt in the present-day Western Cordillera (Horton et al., 2001, 2002). Protracted Paleogene uplift may explain the lack of Eocene equivalents towards the north, in the
Belén region, where a hiatus separates the Middle Jurassic from the Oligocene-Miocene sequences (García et al., 2004).

As the Mesozoic substratum is directly involved in the deformation, the style was thick-skinned. The angular unconformity between the Utayane and Icanche Formations, in the vicinity of the Aquine fault which affects the Eocene Icanche Formation, indicates that this structure was active prior to the latest Oligocene (ca. $>27 \mathrm{Ma}$ ). Although the constraints on the timing are broad, post $49 \mathrm{Ma}$ and pre $27 \mathrm{Ma}$, the deformation is likely related to the middle Eocene Incaic phase. In the Precordillera, Paleogene contraction and consequent erosion and denudation gave rise to the regionally flat, erosive, Choja Pediplain unconformity (Galli, 1967). Block exhumation in the Eastern Cordillera was triggered during the late Eocene-early Oligocene (36-27 Ma) (Barnes et al., 2012), synchronic to or slightly later than this first period of contraction in the western Altiplano.

\footnotetext{
${ }^{3}$ Blanco, N.; Vásquez, P.; Sepúlveda, F.; Tomlinson, A.; Quezada, A.; Ladino, M. 2012. Levantamiento geológico para el fomento de la exploración de recursos minerales e hídricos de la Cordillera de la Costa, Depresión Central y Precordillera de la Región de Tarapacá (20-21 $\left.{ }^{\circ} \mathrm{S}\right)$. Informe Registrado IR-12-50, Servicio Nacional de Geología y Minería, Subdirección Nacional de Geología: 246 p. Santiago.
} 


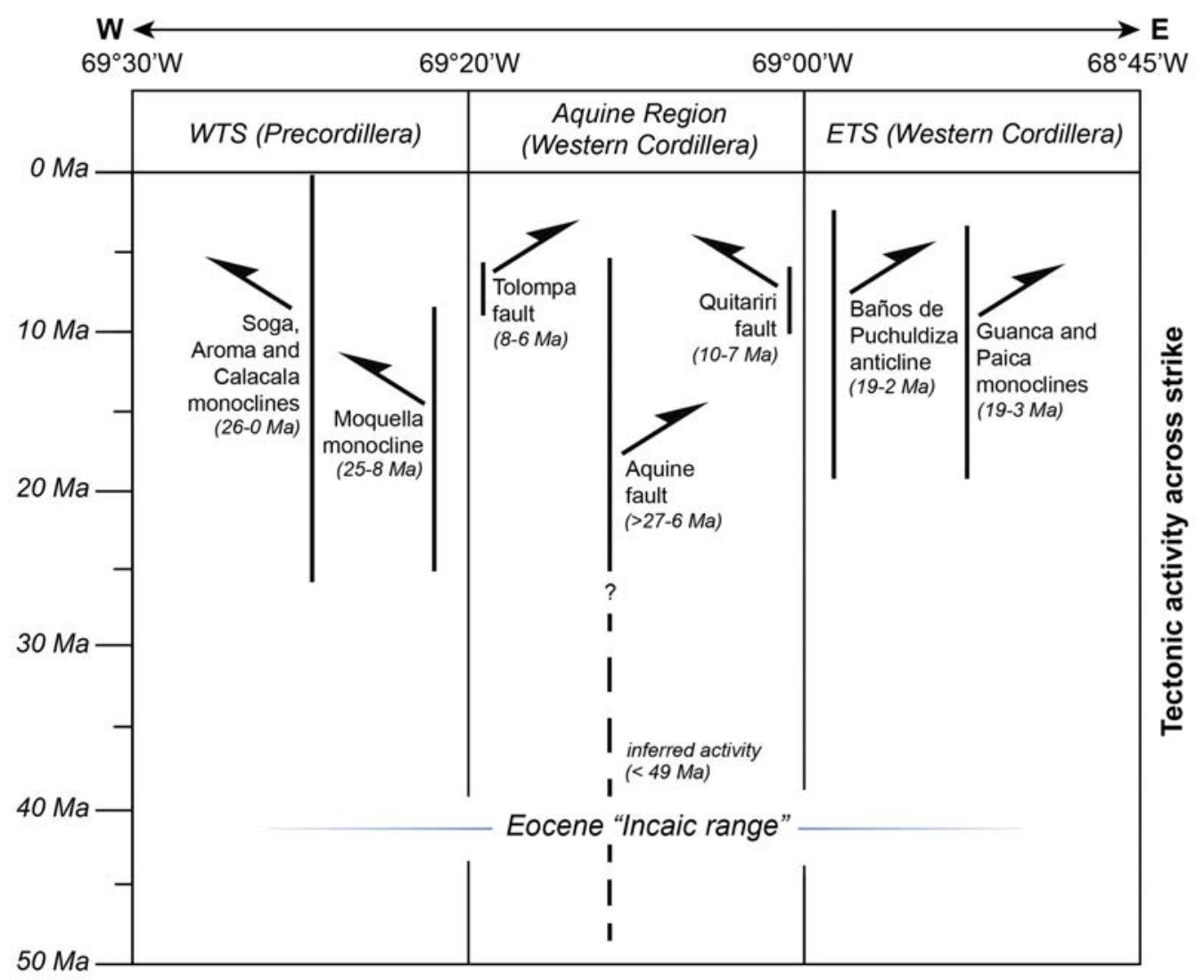

FIG. 10. Correlation of Cenozoic tectonic activity across the Precordillera and Western Cordillera at $\sim 19^{\circ} 15^{\prime}$ S. Timing of deformation at the Precordillera (WTS) is depicted after Pinto et al. (2004) and Farías et al. (2005). Timing of deformation at the Western Cordillera (ETS) is depicted after Cortés et al. (2012a, 2014).

\subsection{Second episode (27-14 Ma)}

Regarding the early Neogene structural evolution of the Western Cordillera, the unconformity between the Utayane and Puchuldiza Formations indicates a second period of contraction during the late Oligocene-middle Miocene (ca. 27-14 Ma) (Figs. 9c and 11b), in which the Utayane Formation was tilted towards the east, above the already deformed Icanche Formation. This second period is synchronic to the initial development of the Interandean Zone and Subandean Sierras, east of the Altiplano (McQuarrie et al., 2005; Barnes et al., 2012).

A Oligocene volcanic lull lasted until the late Oligocene-early Miocene (Trumbull et al., 2006), when regional-scale explosive volcanism gave origin to the Utayane and Oxaya Formations (Figs. 9b and $11 \mathrm{~b}$ ) concomitant to a strong peak in plate convergence rates at ca. $25 \mathrm{Ma}$ (Somoza, 1998). As the Oxaya Formation lies at the eastern margin of the Precordillera, and it is not exposed in the Western Cordillera (e.g., García et al., 2004; Valenzuela et al., 2014; this study), and considering that the Utayane Formation only outcrops east of the Aquine fault at the southeastern portion of the Aquine region, we attribute this absence of pyroclastic deposits of this age (west and north of the Aquine fault in the study area) to the occurrence of a positive relief, uplifted by substratum-involving faults (Fig. 9b). A gradual eastward thickening of the Utayane Formation has also been registered east and south of the Aquine region, where this unit reaches a $\sim 200$ to $600-1,000 \mathrm{~m}$ thickness increase, suggesting that deposition of the former developed at the Western Cordillera but concentrated towards the east, in the westernmost Altiplano basin (Cortés et al., 2014; Sellés et al., 


\section{A) Middle Eocene}

w

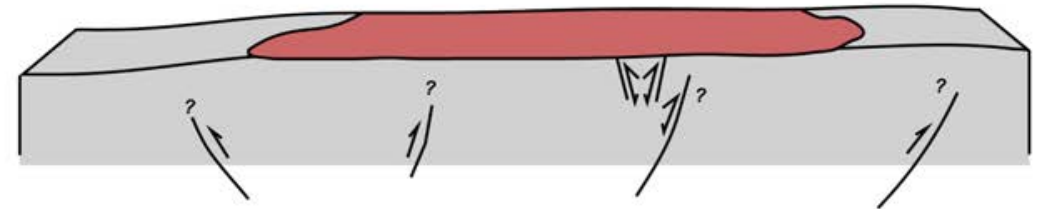

B) Upper Oligocene-lower Miocene

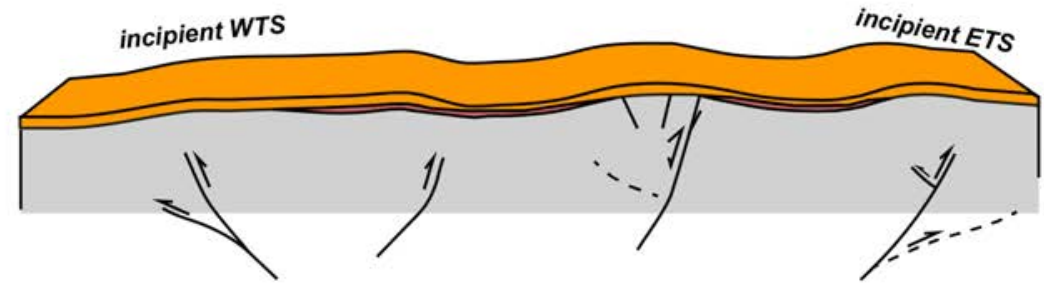

C) Middle-upper Miocene

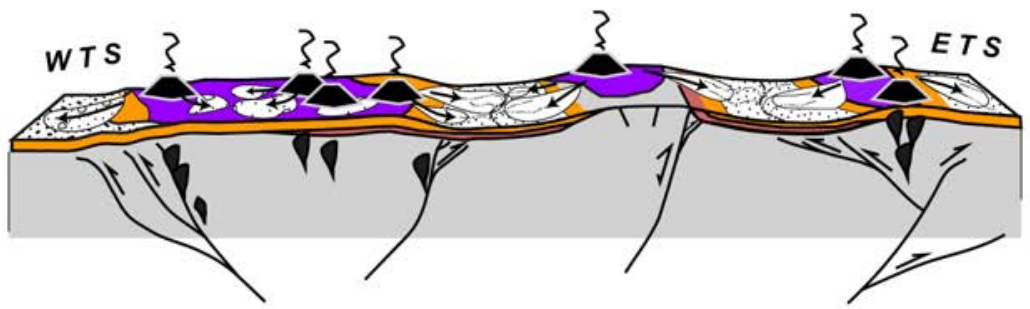

\section{D) Present-day structural configuration}

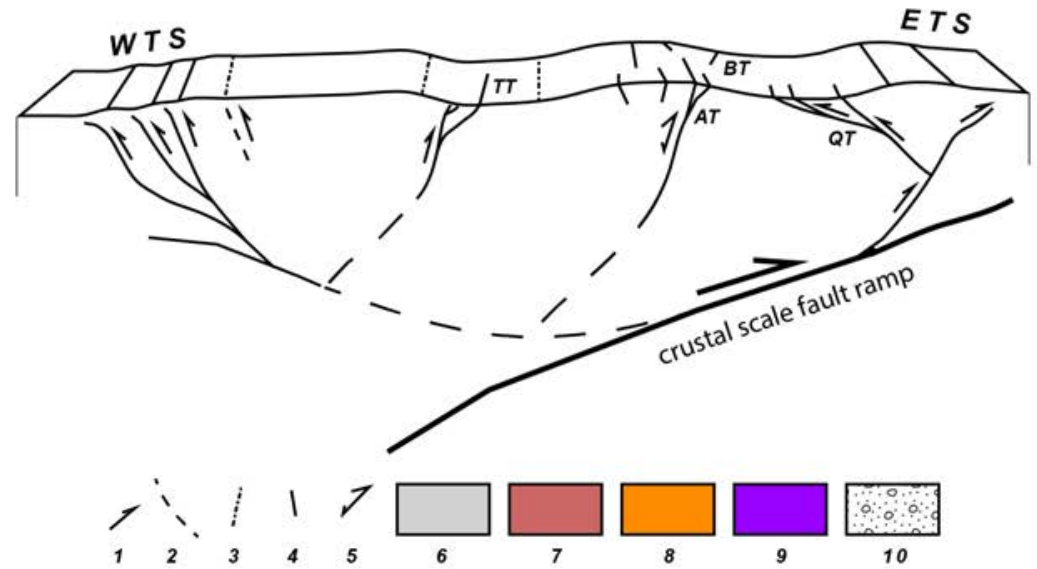

FIG. 11. Integrated model for the Cenozoic structural and depositional evolution of the Western Cordillera at $\sim 19^{\circ} 20^{\prime}$ S. Approximate trace of the present-day structural configuration is shown in figure 2. The deep structure of the WTS and ETS are schematically drawn from Farías et al. (2005) and Cortés et al. (2012a), respectively. The crustal scale fault bend fold is drawn from Farías et al. (2005). Schematic development of the Aquine and Quitariri thrusts is explained in figure 9. Simbology: 1. Reverse fault; 2. Inferred in-depth structure; 3. Inferred superficial trace of structure; 4. Surface fault and fold traces; $\mathbf{5}$. Inversely reactivated normal fault; 6. Deformed Mesozoic substratum; 7. Eocene ignimbrites (Icanche Formation); 8. Oligocene-Miocene ignimbrites (Oxaya and Utayane Formations); 9. Miocene andesitic lavas and volcanic sequences; 10. Miocene sedimentary rocks. TT: Tolompa fault; BT: Berenguela fault; AT: Aquine fault; QT: Quitariri fault. 
in press). The positive relief in the Aquine region would have restricted deposition of pyroclastic flows to depressed areas or prompted erosion of the deposits from topographic highs. In the Western Cordillera of the Belén Region, the Oligocene-Miocene explosive volcanic event is registered in the Lupica Formation (García et al., 2004; Charrier et al., 2005, 2007, 2013), which exhibits growth strata probably associated with normal faulting near the Oligocene-Miocene boundary, suggesting the existence of calderas along the present-day Precordillera and Western Cordillera (Charrier et al., 2013), likely to be the source of the pyroclastic deposits in the Oxaya and Utayane Formations.

\subsection{Third episode (14-6 Ma)}

East-vergent folds within the Puchuldiza Formation were developed adjacent to the Aquine reverse fault. As the Aquine fault is sealed by upper Miocene volcanic sequences of the Tatajachura volcano at the Aroma valley, the youngest movement along the reverse fault is prior to $c a$. $6 \mathrm{Ma}$ (lavas of the Tatajachura volcano; Morandé et al., 2014), which indicates a third period of compressive deformation during the middle-latest Miocene ( $\mathrm{ca}$. 14-6 Ma) (Figs. 9d and 11c). The Tolompa fault and associated east-vergent folds, as well as the Berenguela fault and adjacent syncline, in the northern portion of the study area, also developed during this time span, most likely during the latest Miocene.

Volcanism during the middle Miocene, represented by the Puchuldiza Formation and the Guaillane Ignimbrite was more or less concomitant to the latest stages of deposition of the sedimentary Chucal Formation and the volcanic and sedimentary Macusa Formation in the Belén region (Fig. 3, García et al., 2004; Charrier et al., 2005, 2013). In the Aquine region, the Miocene Mauque Formation represents the occurrence of humid alluvial fans and associated braided rivers throughout their middle and distal portions, developed in exoreic intramontane basins (Argandoña, 1984; Cortés et al., 2014; Valenzuela et al., 2014; Bobadilla, 2015; Herrera et al., 2015), adjacent to Middle and Upper Miocene volcanic edifices (Fig. 11c), which are still partially conserved in the study area and its surroundings. Given the geochemical and lithological affinity of Miocene volcanic products and clastic content of the Mauque Formation (Bobadilla, 2015), in addition to the fact that detrital $\mathrm{U}-\mathrm{Pb}$ zircon analyses for the Mauque Formation yielded strong middle-Miocene peaks, we argue that products of the erosion of middle Miocene volcanoes would be the main source of the successions clastic content. Specifically, geochronological analyses for lavas of the Mamuta volcano, which yielded ages of $c a .14 \mathrm{Ma}$ (Seguel et al., 1991; Valenzuela et al., 2014), in addition to ages yielded from U-Pb zircon and K-Ar on biotite analyses carried out for the underlying Puchuldiza Formation (ca. $14 \mathrm{Ma}$; Ortiz et al., 2008; Cortés et al., 2014; Valenzuela et al., 2014), indicate that these units would likely correspond to the predominant detrital source for the Mauque Formation.

As the Mauque Formation (ca. 14-8 Ma) is in part synchronic to and involved in the thrust system controlled by the Quitariri fault within the southeastern portion of the study area, deformation can be constrained by the age of the Putoyane Ignimbrite (7 Ma) which covers and seals folds related to the fault in the Macurquima valley. Hence, overlapping the third period, compressive deformation took place during the late Miocene (ca. 10-7 Ma) (Figs. 9d and $11 \mathrm{c}$ ). Style of deformation in the southeastern portion of the study area is west-vergent and thinskinned at the surface, although substratum-rooting of thrusts at depth cannot be discarded (Fig. 9d). Movement along the Quitariri and related thrusts is likely to be a result of late Miocene back-thrusting related to activity of a deeply rooted west-dipping thrust of the ETS; which probably corresponds to the westernmost strand of the system in the Cariquima region which passes through the Puchuldiza area (Figs. 9d and 11c) (Cortés et al., 2012a). There is no evidence for neotectonic deformation in the study area, nor post-7 Ma deformation.

Growth strata relations observed in the Macurquima valley (Fig. 7), and synsedimentary structures, such as slumping and recumbent stratification, within sandstone layers, suggests a syntectonic interpretation for the development of the Mauque Formation in the Aquine region (e.g., Bobadilla, 2015; Herrera et al., 2015). Although the structural style is clear for deformation during the Miocene in the Western Cordillera, the tectonic regime in which the Mauque Formation accumulated, compressional or extensional, is subject of debate (Bobadilla, 2015; Herrera et al., 2015). In the Belén region, the Chucal Formation registers a similar syntectonic development of deposition. Lacustrine sedimentation was followed 
by fluvial sedimentation during the lower to middle Miocene, with concomitant alluvial fans which are represented by a coarsening-up sedimentary sequence that exhibits eastward-fanning growth strata (Charrier et al., 2005). These growth strata and progressive unconformities within the formation are associated with the growth of the Chucal anticline, which is inferred to be related to a blind thrust (García et al., 2004; Charrier et al., 2005). In spite of the diachronic lapses of deposition for the Chucal and Mauque Formations, the observed growth strata relations in the overturned limb of the west-vergent anticline in the Macurquima valley indicate that the Mauque Formation also accumulated under compressive tectonic conditions during the middle to late Miocene. Moreover, the syntectonic deposition of the El Diablo Formation (ca. 16-8 Ma) in the Precordillera at $\sim 19^{\circ} 15^{\prime} \mathrm{S}$, directly related to the development of the WTS (Pinto et al., 2004; Farías et al., 2005), and roughly coeval to the deposition of the Mauque Formation, suggests that sedimentation and volcanism developed throughout the Precordillera and Western Cordillera under active compressive tectonic conditions (Figs. 10 and 11c).

Upper Miocene volcanism continued in the Western Cordillera until present without major interruptions, generating andesitic lava sequences and pyroclastic flow deposits (upper Miocene, Pliocene, Pleistocene and Quaternary volcanic sequences).

\subsection{Relationship with the WTS and ETS}

With respect to the bordering structural systems, deformation along the WTS occurred at: $21 \mathrm{Ma}$ at $\sim 19^{\circ} 15^{\prime} \mathrm{S}$ (Pinto et al., 2004), $26 \mathrm{Ma}$ at $\sim 19^{\circ} 20^{\prime} \mathrm{S}$ (Farías et al., 2005), and $30 \mathrm{Ma}$ at $18^{\circ}-19^{\circ} \mathrm{S}$ (García, 2002) and $20^{\circ}-21^{\circ} \mathrm{S}$ (Victor et al., 2004). Meanwhile, deformation on the ETS commenced at $21 \mathrm{Ma}$ at $\sim 18^{\circ} 40^{\prime} \mathrm{S}$ (Charrier et al., 2005), and at ca. 23 Ma at $\sim 19^{\circ} 30^{\prime} \mathrm{S}$ (Cortés et al., 2012a) (Fig. 10). Neogene activity of the WTS in the Precordillera is considered to be continuous, although at varying deformation rates during the Miocene (e.g., Pinto et al., 2004; Victor et al., 2004; Farías et al., 2005). Peaks of increased deformation have been identified in the Precordillera at $\sim 20^{\circ}-21^{\circ} \mathrm{S}$ during $c a$. $25 \mathrm{Ma}$ and ca. 12-10 Ma (Victor et al., 2004), and roughly coincide with the second and third episodes of contraction registered in the Aquine region. Rapid relative uplift along the WTS has been tracked for most of the Miocene (ca. 26-8 Ma; Farías et al., 2005), concomitant to Neogene deformation at the Aquine region (Fig. 10). In regards to the ETS, Neogene activity is also considered to be continuous for most of the period, in a $\sim 18 \mathrm{Myr}$ timespan between ca. 21-3 Ma, in which at least four compressive events took place in the Western Cordillera through eastvergent thin-skinned thrusts and folds at $\sim 18^{\circ} 40^{\prime} \mathrm{S}$ (Jaropilla thrust and Chucal anticline; García et al., 2004; Charrier et al., 2005). At $\sim 19^{\circ} 15^{\prime}$ 'S, activity of the ETS is constrained to a timespan concomitant to the WTS at the same latitudes, restricted to the Miocene epoch (lower-upper Miocene), rather synchronous to the evolution of the ETS towards the north (Fig. 10) (Cortés et al., 2012a, 2014). We relate the third episode of deformation identified at the Aroma region to backthrusting of the ETS during the latest Miocene.

With relation to the present-day structural configuration of the Western Cordillera (Fig. 11d), the geology outlined indicates the occurrence of oppositely verging thrust faults that limit and uplift crustal blocks that effectively define pop-up structures on the margins and interior of the Precordillera and Western Cordillera. The westernmost pop-up structure is inferred to link the structures of the WTS to the east-vergent thrusts of the Aquine region (Tolompa and Aquine reverse faults). Within the hypothetical pop-up, strike-slip motion has been proposed for the easternmost part of WTS at $20^{\circ}-21^{\circ} \mathrm{S}$ (e.g., Victor et al., 2004). Plate convergence obliquity variations that enhanced dextral along-strike displacements in the Precordillera at $19^{\circ} 30^{\prime} \mathrm{S}$ within the WTS (Soga and Aroma flexures; Farías et al., 2005) are proposed for the present-day geodynamic setting of the arc (Farías et al., 2005). However, no direct evidence has been registered in the Aquine region for transpressive tectonics and hence, we consider that strike-slip motions in our study area appear doubtful. The easternmost pop-up structure is more evident, and defined by the west-vergent Quitariri fault, which roots into the westernmost thrust of the ETS in the Cariquima Region (Fig. 11d), which, in turn, is proposed to be rooted in the crustal-scale fault ramp of Farías et al. (2005) (Cortés et al., 2012a). This easternmost pop-up can be qualitatively compared to a pop-up structure generated as a back thrust associated to a positively reactivated normal thrust (e.g., Bonini et al., 2012). 
This pop-up array structural style proposed for the Western Cordillera was previously advanced by Farías et al. (2005), Charrier et al. $(2007,2013)$ and Cortés et al. (2012a), and has also been demonstrated for the structure of the Eastern Cordillera in Bolivia (McQuarrie et al., 2005). Towards the ETS and below the Western Cordillera, the crustal-scale fault ramp within the rigid forearc is inferred to flatten towards the Altiplano where it corresponds to the ALVZ (Altiplano Low Velocity Zone in ANCORP, 2003; Farías et al., 2005; Cortés et al., 2012a). We note that this structural style is consistent with the upper crust structure of the Western Cordillera at the study region (Farías et al., 2005; Cortés et al., 2012a), and that similarly, it develops in the local (singular structure), regional (several structures) and crustal (bordering thrust systems) scale. Analogue experiments for compressive systems (Venegas and Nalpas, 2005) indicate that pop-up structures and deformation distributed over large zones is favored where the compressive belt has not undergone massive surface erosion during its development, such as the Western Cordillera (García et al., 2011).

Hypothetically, the structure of the Western Cordillera is linked at depth with the WTS and ETS by means of the crustal-scale west-dipping fault ramp of Farías et al. (2005) (Fig. 11d). The schematic geometry of our conceptual model (Fig. 11d) is qualitatively comparable to the crustal-scale architecture proposed for the Principal Cordillera of the Andes in Central Chile $\left(\sim 33^{\circ} \mathrm{S}\right)$ (Farías et al., 2010).

In regards to the overall timing of deformation, the unconformities exposed amongst the Neogene formations, particularly in the Macurquima valley, suggest the repeated occurrence of contraction during this period in the Western Cordillera, at least for the time span between deposition of the Utayane Formation and the Putoyane Ignimbrite (ca. 27-7 Ma), meaning the tectonic activity may have spanned as much as $c a$. 20 Myr. This lapse was preceded by a middle to late Paleogene compressive phase of an undetermined duration. The present-day Western Cordillera appears to be situated in a structural block that absorbed deformation through most of the Cenozoic (Fig. 10), which corresponds to the "Incaic relief" of Charrier et al. (2007, 2013). This relief has marked the drainage divide between the Altiplano basin and the Central Depression basin since at least the Eocene (Charrier et al., 2013).
As onset and development of deformation in the Aquine region was concomitant to uplift within the eastern Altiplano (Barnes et al., 2012), we interpret that contraction in the study area has contributed to uplift of the western flank of the Andean plateau as part of a long-lived compressive structural system comprised by the WTS, the ETS and the intervening structure of the Western Cordillera.

\section{Concluding remarks}

The Western Cordillera (WC) in the Aquine region experienced contractional deformation in the middle or late Paleogene, concomitant with uplift in the Eastern Cordillera of Bolivia, and was afterwards characterized by a compressive tectonic regime throughout most of the Neogene, in the ca. 27-7 Ma time span, concomitant to deformation in the Interandean Zone and the Subandean Sierras of Bolivia.

During the Neogene, the WC experienced three main episodes of contraction: a middle Eocene-late Oligocene ( $c a .49-27 \mathrm{Ma}$ ) episode, a late Oligocenemiddle Miocene (ca. 27-14 Ma) episode, and a middle to latest Miocene episode ( $c a$. 14-6 Ma). Synchronically, sedimentation and volcanism developed throughout the Precordillera and Western Cordillera under active compressive tectonic conditions, resembling the tectonostratigraphic evolution of the $\mathrm{WC}$ at $18^{\circ}-19^{\circ} \mathrm{S}$.

Deformation was accomplished by means of NNW to SSE striking, high-angle, substratuminvolving, thrusts and associated folds, in addition to a low-angle fold-and-thrust belt that constitute a doubly vergent structural domain located between the West Vergent Thrust System, located at the foot of the Precordillera, and the East Vergent Thrust System located within the WC, immediately east of the Aquine region. The structural style within the WC indicates a combination of thin- and thick-skinned deformation. This character is also exhibited by the West Vergent Thrust System in the Precordillera and inferred for the East Vergent Thrust System towards the westernmost Altiplano. Together with the bordering thrust systems, the overall structure of the WC resembles a crustal-scale "pop-up" structure.

The high-angle character of substratum-involving thrusts in the WC suggests an inheritance of preCenozoic extensional structures within the Mesozoic substratum that underwent positive inversion during 
the Cenozoic, highlighting the importance of extensional structural inheritance in the construction of the uppermost crust of the present-day Andes of northernmost Chile.

\section{Acknowledgements.}

This study is part of the 1:100.000-scale basic geology mapping project encompassed in the Plan Nacional de Geología of the Servicio Nacional de Geología y Minería (SERNAGEOMIN, Chile). We specially thank reviewers A.J. Tomlinson (SERNAGEOMIN) for a thorough first revision of this manuscript that led to a major improvement of the text and figures, and Professor R. Charrier (Universidad de Chile) for providing constructive comments and suggestions that greatly enhanced our contribution. The authors also thank I. del Real (University of British Columbia) for fieldwork and structural interpretations at an early stage of this study; P. Bobadilla (Universidad de Chile) for fieldwork and for sharing the detailed sedimentology and stratigraphy of the Mauque Formation from his thesis project; J. Vargas and R. Valles (Universidad de Chile) for zircon sample preparation; L. Solari (UNAM) for the U-Pb LA-ICP-MS analyses; and S. Bascuñán and P. Molina (Universidad de Chile) for helpful discussions on the structural and stratigraphical approaches as well as geochronological aspects addressed in the paper.

\section{References}

Allmendinger, R.; Jordan, T.; Kay, S.M.; Isacks, B. 1997. The evolution of the Altiplano-Puna plateau of the Central Andes. Annual Reviews of Earth and Planetary Sciences 25: 139-174.

Amilibia, A.; Sàbat, F.; McClay, K.R.; Muñoz, J.A.; Roca, E.; Chong, G. 2008. The role of inherited tectono-sedimentary architecture in the development of the central Andean mountain belt: Insights from the Cordillera de Domeyko. Journal of Structural Geology 30: 1520-1539.

ANCORP Working group. 2003. Seismic imaging of a convergent continental margin and plateau in the central Andes (Andean Continental Research Project 1996 (ANCORP'96)). Journal of Geophysical Research 108 (B7), 2328: 1-25

Argandoña, R. 1984. Geología del cuadrángulo Cerro Socora y características generales del área geotermal de Puchuldiza. Memoria de Título (Unpublished), Universidad de Chile, Departamento de Geología: 166 p.

Arriagada, C.; Cobbold, P.R.; Roperch, P. 2006. Salar de Atacama basin: A record of compressional tectonics in the central Andes since the mid-Cretaceous. Tectonics 25, TC1008: 1-19.

Arriagada, C.; Roperch, P.; Mpodozis, C.; Cobbold, P.R. 2008. Paleogene building of the Bolivian Orocline: Tectonic restoration of the central Andes in 2-D map view. Tectonics 27, TC6014: 1-14.

Bahlburg, H.; Hervé, F. 1997. Geodynamic evolution and tectonostratigraphic terranes of northwestern Argentina and northern Chile. Geological Society of America Bulletin 7: 869-884.

Barnes, J.B.; Ehlers, T.A. 2009. End member models for Andean Plateau uplift. Earth-Science Reviews 97: 117-144.

Barnes, J.B.; Ehlers, T.A.; McQuarrie, N.; O’Sullivan, P.B.; Tawackoli, S. 2008. Thermochronometer record of central Andean plateau growth, Bolivia $\left(19.5^{\circ}\right)$. Tectonics 27, TC3003: 1-25.

Barnes, J.B.; Ehlers, T.A.; Insel, N.; McQuarrie, N.; Poulsen, C.J. 2012. Linking orography, climate, and exhumation across the central Andes. Geology 40 (12): 1135. doi: 10.1130/G33229.1.

Bascuñán, S.; Arriagada, C.; Le Roux, J.; Deckart, K. 2015. Unravelling the Peruvian Phase of the Central Andes: stratigraphy, sedimentology and geochronology of the Salar de Atacama Basin $\left(22^{\circ} 30^{\prime}-23^{\circ} \mathrm{S}\right)$, northern Chile. Basin Research 2015: 1-28.

Basei, M.A.; Charrier, R.; Hervé, F. 1996. New ages (U-Pb, Rb-Sr, ${ }^{39} \mathrm{~K}-{ }^{40} \mathrm{Ar}$ ) from supposed Precambrian units in Chile: some geotectonic implications. In Proceedings of the International Symposium on Andean Geodynamics, No 3, editorial ORSTOM: 763-766. Saint Malo.

Blanco, N.; Tomlinson, A. 2013. Carta Guatacondo, Región de Tarapacá. Servicio Nacional de Geología y Minería, Carta Geológica de Chile, Serie Geología Básica 156, 1 mapa escala 1:100.000. Santiago.

Bobadilla, P. 2015. Análisis del ambiente tectonosedimentario de la Formación Mauque y su implicancia durante el Mioceno tardío, Región de Tarapacá (19 $\left.15^{\circ} \mathrm{S} / 6^{\circ} 15^{\circ} \mathrm{W}\right)$. Memoria de Título (Unpublished), Departamento de Geología, Universidad de Chile. 116 p.

Bonini, M.; Sani, F.; Antonielli, B. 2012. Basin inversion and contractional reactivation of inherited normal faults: A review based on previous and new experimental models. Tectonophysics 522-523: 55-88.

Charrier, R.; Chávez, A.; Elgueta, S.; Hérail, G.; Flynn, J.; Croft, D.; Wyss, A.; Riquelme, R.; García, M. 2005. Rapid tectonic and paleogeographic evolution associated with the development of the Chucal anticline and the Chucal-Lauca Basin in the Altiplano of Arica, 
northern Chile. Journal of South American Earth Sciences 19: 35-54.

Charrier, R.; Pinto, L.; Rodríguez, M.P. 2007. Tectonostratigraphic evolution of the Andean Orogen in Chile. In The Geology of Chile (Gibbons W., Moreno, T.; editors). The Geological Society, Special Publication: 21-116. London.

Charrier, R.; Farías, M.; Maksaev, V. 2009. Evolución tectónica, paleogeográfica y metalogénica durante el Cenozoico en los Andes de Chile norte y central e implicaciones para las regiones adyacentes de Bolivia y Argentina. Revista de la Asociación Geológica Argentina 65: 5-35.

Charrier, R.; Hérail, G.; Pinto, L.; García, M.; Riquelme, R.; Farías, M.; Muñoz, N. 2013. Cenozoic tectonic evolution in the Central Andes in northern Chile and west central Bolivia: Implications for paleogeographic, magmatic and mountain building evolution. International Journal of Earth Sciences 102: 235-264.

Cornejo, P.; Matthews, S.; Pérez de Arce, C. 2003. The "K-T" compressive deformation event in northern Chile (24-27 $\mathrm{S})$. In Congreso Geológico Chileno No. 10, Resumen Extendido, CD-ROM. Concepción.

Cortés, J.; Farías, M.; Comte, D.; Charrier, R. 2012a. Estructuras y depósitos neógenos de la región de Cariquima (Altiplano chileno): Implicancias en el origen de la Cordillera Occidental a los $19^{\circ} 30^{\prime} \mathrm{S}$. In Congreso Geológico Chileno, No. 13, Actas: 229-231. Antofagasta.

Cortés, J.; Del Real, I.; Pinto, L.; Farías, M.; Herrera, S.; Castruccio, A. 2012b. Primeros resultados de la Geología y Estructura de la Precordillera y Cordillera Occidental entre los $19^{\circ} 15^{\prime}$ y $19^{\circ} 30^{\prime}$ S (I Región de Tarapacá, Chile). In Congreso Geológico Chileno No. 13, Actas: 229-231. Antofagasta.

Cortés, J.; Cascante, M.; Zavala, V. 2014. Geología de las Áreas Isluga y Sierra de Huaillas, Región de Tarapacá. Servicio Nacional de Geología y Minería, Carta Geológica de Chile, Serie Geología Básica 172-173, 1 mapa escala 1:100.000.

Dewey, J.F.; Bird, J.M. 1970. Mountain belts and the new global tectonics. Journal of Geophysical Research 75: 2625-2647.

Elger, K.; Oncken, O.; Glodny, J. 2005. Plateau-style accumulation of deformation, southern Altiplano. Tectonics 24, TC4020: 1-19.

Farías, M.; Charrier, R.; Comte, D.; Martinod, J.; Hérail, G. 2005. Late Cenozoic deformation and uplift of the western flank of the Altiplano: Evidence from the depositional, tectonic, and geomorphologic evolution and shallow seismic activity (northern Chile at 19³0'S). Tectonics 24, TC4001: 1-27.

Farías, M.; Comte, D.; Charrier, R.; Martinod, J.; David, C.; Tassara, A.; Tapia, F.; Fock, A. 2010. Crustal-scale structural architecture in Central Chile based on seismicity and surface geology: implications for Andean mountain building. Tectonics 29, TC3006: 1-22.

Gallardo, F.; Farías, M.; Morandé, J. 2013. Tracking Mesozoic tectonics in the western slope of the Altiplano in northern Chile and the onset of contractional deformation: evidence from the Tarapacá valley at $19^{\circ} 45^{\prime}$ S. Bollettino di Geofisica 54 suppl. 2. In GeoSur 2013, Resúmenes: 55-56. Viña del Mar.

Galli, C. 1967. Pediplain in northern Chile and the Andean uplift. Science 158: 653-655.

Galli, C.; Dingman, R.J. 1962. Cuadrángulo Pica, Alca, Matilla y Chacarilla con un estudio sobre los recursos de agua subterránea, Provincia de Tarapacá. Instituto de Investigaciones Geológicas, Carta Geológica de Chile. Serie Geología Básica 7-10: 125 p. Santiago.

García, M. 1996. Geología y estructura del borde del Altiplano occidental, en el área de Belén (Chile). Memoria de Título y Tesis de Grado de Magíster en Ciencias mención Geología (Unpublished), Departamento de Geología, Universidad de Chile: $111 \mathrm{p}$.

García, M. 2002. Évolution oligo-néogene del'Altiplano Occidental (Arc et Avant-Arc du Nord du Chili, Arica): Tectonique, volcanisme, sédimentation, géomorphologie et bilan érosion-sédimentation. Tesis de Doctorado (Unpublished), Université Joseph Fourier, Grenoble: 117 p. Francia.

García, M.; Hérail, G. 2005. Fault-related folding, drainage network evolution and valley incision during the Neogene in the Andean Precordillera of Northern Chile. Geomorphology 65: 279-300.

García, M.; Gardeweg, M.; Clavero, J.; Hérail, G. 2004. Hoja Arica, Región de Tarapacá. Servicio Nacional de Geología y Minería, Carta Geológica de Chile, Serie Geología Básica 84: 150 p., 1 mapa escala $1: 250.000$.

García, M.; Riquelme, R.; Farías, M.; Hérail, G.; Charrier, R. 2011. Late Miocene-Holocene canyon incision in the western Altiplano, northern Chile; tectonic or climatic forcing? Bulletin of the Geological Society of London 168: 1047-1070.

García, M.; Fuentes, G.; Riquelme, F. 2013. Carta Miñimiñi, Regiones de Arica y Parinacota y de Tarapacá. Servicio Nacional de Geología y Minería, Carta Geológica 
de Chile, Serie Geología Básica 157: 49 p., 1 mapa escala 1:100.000.

Garzione, C.N.; Molnar, P.; Libarkin, J.C.; MacFadden, B. 2006. Rapid late Miocene rise of the Andean plateau: evidence for removal of mantle lithosphere. Earth and Planetary Science Letters 241: 543-556.

Garzione, C.N.; Auerbach, D.J.; Smith, J.J.; Rosario, J.J.; Passey, B.H.; Jordan, T.E.; Eiler, J.M. 2014. Clumped isotope evidence for diachronous surface cooling of the Altiplano and pulsed surface uplift of the Central Andes. Earth and Planetary Science Letters 393: 173-181.

Gregory-Wodzicki, K. 2000. Uplift history of central and northern Andes: A review, Geological Society of America Bulletin 112: 1091-1105.

Harambour, S. 1990. Geología pre-Cenozoica de la Cordillera de Los Andes entre las Quebradas Aroma y Juan de Morales, I Región. Memoria de Título (Unpublished), Universidad de Chile: 228 p. Santiago.

Hartley, A.J.; Evenstar, L. 2010. Cenozoic stratigraphic development in the northern Chilean forearc: Implications for basin development and uplift history of the Central Andean margin. Tectonophysics 495: 67-77.

Herrera, S.; Pinto, L.; Valenzuela, J.I.; Cortés, J. 2013. Cenozoic tectonostratigraphy of the Western Cordillera: a conceptual model for its origin and evolution (northern Chile at $\sim 19^{\circ} 20^{\prime} \mathrm{S}$ ). Bollettino di Geofisica, 54 suppl. 2. In GeoSur 2013, Resúmenes: p. 69. Viña del Mar.

Herrera, S.; Bobadilla, P.; Pinto, L. 2015. Sedimentación y deformación de la Formación Mauque durante el Mioceno: Implicancias tectónicas (Cordillera Occidental; norte de Chile a los $\left.19^{\circ} 15^{\prime} \mathrm{S}\right)$. In Congreso Geológico Chileno No. 14, Actas: 4 p. La Serena.

Hoke, G.D.; Isacks, B.L.; Jordan, T.E.; Blanco, N.; Tomlinson, A.J.; Ramezani, J. 2007. Geomorphic evidence for post-10 Ma uplift of the western flank of the central Andes $18^{\circ} 30^{\prime}-22^{\circ} \mathrm{S}$. Tectonics 26, TC5021: 1-17.

Horton, B.K.; Hampton, B.A.; Waanders, G.L. 2001. Paleogene synorogenic sedimentation in the Altiplano plateau and implications for initial mountain building in the central Andes. Geological Society of America Bulletin 113 (11): 1387-1400.

Horton, B.K.; Hampton, B.A.; Lareau, B.N.; Baldellón, E. 2002. Tertiary provenance history of the northern and central Altiplano (Central Andes, Bolivia): A detrital record of plateau-margin tectonics. Journal of Sedimentary Research 72 (5): 711-726.

Isacks, B.L.1988. Uplift of the central Andean plateau and bending of the Bolivian Orocline, Journal of Geophysical Research 93: 3211-3231.

Jaillard, E. 1992. La Fase Peruana en la Margen Peruana (Cretáceo Superior). Boletín de la Sociedad Geológica del Perú 83: 81-87.

Jordan, T.E.; Nester, P.L.; Blanco, N.; Hoke, G.D.; Dávila, F.; Tomlinson, A.J. 2010. Uplift of the Altiplano-Puna plateau: A view from the west. Tectonics 29, TC5007: 1-31.

Lahsen, A.; Sepúlveda, F.; Rojas, J.; Palacios, C. 2005. Present Status of Geothermal Exploration in Chile. In World Geothermal Congress 2005: 24-29. Antalya.

Lamb, S.; Hoke, L.; Kennan, L.; Dewey, J. 1997. Cenozoic evolution of the Central Andes in Bolivia and northern Chile. In Orogeny Through Time (Burg, J.P.; Ford, M.; editors), Geological Society Special Publication 121: 237-264.

Loewy, S.L.; Connelly, J.N.; Dalziel, I.W.D. 2004. An orphaned basement block: The Arequipa-Antofalla Basement of the central Andean margin of South America. Geological Society of America Bulletin 116: 171-187.

Ludwig, K.R. 2008. Isoplot 3.7. Berkeley Geochronology Center, Special publication 4: 1-77.

Maksaev, V. 1978. Cuadrángulo Chitigua y sector oriental del Cuadrángulo Cerro Palpana, Región de Antofagasta, Escala 1:50.000. Instituto de Investigaciones Geológicas, Carta Geológica de Chile 31: 55 p. Santiago.

Marques, F.O.; Nogueira, C.R. 2008. Normal fault inversion by orthogonal compression: Sandbox experiments with weak faults. Journal of Structural Geology 30: 761-766.

Martínez, F.; Arriagada, C.; Peña, M.; Del Real, I.; Deckart, K. 2013. The structure of the Chañarcillo Basin: An example of tectonic inversion in the Atacama region, northern Chile. Journal of South American Earth Sciences 42: 1-16.

McQuarrie, N.; Horton, B.K.; Zandt, G.; Beck, S.; De Celles, P.G. 2005. Lithospheric evolution of the Andean fold-thrust belt, Bolivia, and the origin of the central Andean plateau. Tectonophysics 399: 15-37.

Mégard, F. 1984. The Andean orogenic period and its major structures in central and northern Peru. Journal of the Geological Society of London 141: 893-900. 
Montgomery, D.R.; Balco, G.; Willet, S.D. 2001. Climate, tectonics, and the morphology of the Andes. Geology 29: 579-582.

Morandé, J.; Gallardo, F.; Farías, M. 2015. Carta Guaviña, Región de Tarapacá. Servicio Nacional de Geología y Minería, Carta Geológica de Chile, Serie Geología Básica 177. 1 mapa escala 1:100.000.

Muñoz, N.; Sepúlveda, P. 1992. Estructuras compresivas con vergencia al oeste en el borde oriental de la Depresión Central, norte de Chile (19¹5'S). Revista Geológica de Chile 19 (2): 241-247. doi: 10.5027/ andgeoV19n2-a07.

Muñoz, N.; Charrier, R. 1996. Uplift of the western border of the Altiplano on a west-vergent thrust system, northern Chile. Journal of South American Earth Sciences 9: 171-181.

Pacci, D.; Hervé, F.; Munizaga, F.; Kawashita, K.; Cordani, U. 1980. Acerca de la edad Rb-Sr precámbrica de rocas de la Formación Esquistos e Belén, Departamento de Parinacota, Chile. Revista Geológica de Chile 11: 43-50. doi: 10.5027/andgeoV7n3-a03.

Pardo-Casas, F.; Molnar, P. 1987. Relative motion of the Nazca (Farallon) and South American plates since Late Cretaceous times. Tectonics 6: 233-248.

Paton, C.; Woodhead, J.D.; Hellstrom, J.C.; Hergt, J.M.; Greig, A.; Maas R. 2010. Improved laser ablation $\mathrm{U}-\mathrm{Pb}$ zircon geochronology through robust downhole fractionation correction. Geochemistry, Geophysics Geosystems 11: 1525-2027.

Petrus, J.A.; Kamber, B.S. 2012. VizualAge: A novel approach to laser ablation ICP-MS U-Pb geochronology data reduction. Geostandards and Geoanalytical Research 36: 247-270.

Pinto, L.; Hérail, G.; Charrier, R. 2004. Sedimentación sintectónica asociada a las estructuras Neógenas en la Precordillera de la zona de Moquella (19¹5'S, norte de Chile). Revista Geológica de Chile 31 (1): 19-44. doi: 10.5027/andgeoV31n1-a02.

Reutter, K.J. 2001. Le Ande centrali: elemento di un'orogenesi di margine continentale attivo. Acta Naturalia de l'Ateneo Parmense 37: 5-37.

Riquelme, R. 1998. Estratigrafía y deformación de las unidades cenozoicas del borde altiplánico chileno $\left(18^{\circ} 35^{\prime}-19^{\circ} 00^{\prime} \mathrm{S} / 69^{\circ} 00^{\prime}-69^{\circ} 30^{\prime} \mathrm{W}\right)$. Memoria de Título y Tesis de Grado de Magíster en Ciencias, mención Geología (Unpublished), Departamento de Geología, Universidad de Chile: 124 p.

Scheuber, E.; Reutter, K.J. 1992. Magmatic arc tectonics in the central Andes between $21^{\circ}$ and $25^{\circ}$. Tectonophysics 205: 127-140.
Seguel, J.E.; Lahsen, A.; Vergara, M. 1991. Contribución al conocimiento del Complejo Volcánico MamutaGuaichane, Pre-Cordillera de Iquique, Región de Tarapacá: un Complejo Volcánico del Mioceno Medio a superior. In Congreso Geológico Chileno No. 6, Actas 1: 368-372. Viña del Mar.

Sellés, D.; Gardeweg, M.; Garibaldi, N. 2016. Geología del Área Pampa Lirima-Cancosa, Región de Tarapacá. Servicio Nacional de Geología y Minería, Carta Geológica de Chile, Serie Geología Básica 182, 1 mapa escala 1:100.000. Santiago.

Sláma, J.; Košler, J.; Condon, D.; Crowley, J.L.; Gerdes, A.; Hanchar, J.M.; Horstwood, M.; Morris, G.; Nasdala, L.; Norberg, N.; Schaltegger, U.; Schoene, B.; Tubrett, M.; Whitehouse, M. 2008. Plesovice zircon-A new natural reference material for $\mathrm{U}-\mathrm{Pb}$ and Hf isotopic microanalysis. Chemical Geology 249: 1-35.

Solari, L.A.; Gómez-Tuena, A.; Bernal, J.P.; Pérez-Arvizu, O.; Tanner, M. 2010. U-Pb zircon geochronology by an integrated LA-ICPMS microanalytical workstation: achievements in precision and accuracy. Geostandards and Geoanalytical Research 34-1: 5-18.

Steinmann, G.1929. Geologie von Peru. Carl Winters Universitats-Buchhandlung: 448 p.

Somoza, R. 1998. Updated Nazca (Farallon)-South America relative motions during the last $40 \mathrm{My}$ : Implications for mountain building in the central Andean region. Journal of South American Earth Sciences 11: 211-215.

Tomlinson, A.J.; Blanco, N. 1997. Structural evolution and displacement history of the West Fault system, Precordillera, Chile: part II, Postmineral history. In Congreso Geológico Chileno No. 8, Actas 3.

Tomlinson, A.; Blanco, N.; Ladino, M. 2015. Carta Mamiña, Región de Tarapacá. Servicio Nacional de Geología y Minería, Carta Geológica de Chile, Serie Geología Básica 174 p., 1 mapa escala 1:100.000. Santiago.

Trumbull, R.B.; Riller, U.; Oncken, O.; Scheuber, E.; Munier, K.; Hongn, F. 2006. The time-space distribution of Cenozoic volcanism in the South-Central Andes: a new data compilation and some tectonic implications. In The Andes. Springer Berlin Heidelberg: 29-43.

Valenzuela, J.I.; Herrera, S.; Pinto, L; Del Real, I. 2014. Carta Camiña, regiones de Arica-Parinacota y Tarapacá. Servicio Nacional de Geología y Minería, Carta Geológica de Chile, Serie Geología Básica 170: 97 p., 1 mapa escala 1:100.000. 
Venegas, C.; Nalpas, T. 2005. Erosion influence on the evolution of compressive systems constrained by analogue modelling. In International Symposium on Andean Geodynamics (ISAG 2005), No. 6, Extended Abstracts: 779-782.

Victor, P.; Oncken, O.; Glodny, J. 2004. Uplift of the western Altiplano plateau: Evidence from the Precordillera between $20^{\circ}$ and $21^{\circ} \mathrm{S}$ (northern Chile). Tectonics 23, TC4004: 1-24.

Wiedenbeck, M.; Alle, P.; Corfu, F.; Griffin, W.L.; Meier, M.; Oberli, F.; von Quadt, A.; Roddick, J.C.; Spiegel, W. 1995. 3 natural zircon standards for U-Th- $\mathrm{Pb}, \mathrm{Lu}-$ Hf, trace-element and REE analyses. Geostandards Newsletter 19: 1-23.

Manuscript received: December 09, 2015; revised/accepted: February 22, 2017; available online: February 22, 2017. 


\section{Appendix}

\section{Methodology for U-Pb LA-ICPMS geochronology}

Zircon separates from one dacite and three tuff samples have been prepared under standard separation methods at the Geology Department, Universidad de Chile, using the Gemini table, Frantz magnetic separator and heavy liquid procedures. Final grain selection was undertaken by hand, using a binocular. Mineral separates were sent for analyses to the Laboratorio de Estudios Isotópicos (LEI), Geoscience Center, Universidad Nacional Autónoma de México (UNAM), Mexico.

The analytical work was undertaken by using a "Resonetics Resolution M50" $193 \mathrm{~nm}$ laser "Excimer of ArF" connected to a "Thermo Xii Series Quadrupole Mass Spectrometer" following analytical procedures and technical details after Solari et al. (2010). Selected zircon minerals were mounted in epoxy and polished. Employed laser diameter for ablation was between 24 to $34 \mathrm{~mm}$ and reached ablation depth was about 15-25 mm. The Plesovice (337 Ma; Sláma et al., 2008) and 91500 (1065 Ma; Wiedenbeck et al., 1995) international reference zircons were analyzed during age acquisition of the unknown samples. Average ages were calculated and respective plots were obtained using "Isoplot v. 3.7" (Ludwig, 2008). For zircon grains with ages below $1,000 \mathrm{Ma}$, the ${ }^{206} \mathrm{~Pb} /{ }^{283} \mathrm{U}$ ages were considered meaningful as best ages. 


\begin{tabular}{|c|c|c|c|c|c|c|c|c|c|c|}
\hline \multirow{2}{*}{$\begin{array}{l}\text { CS2-4 } \\
\text { spots }\end{array}$} & \multicolumn{10}{|c|}{ CORRECTED AGES ${ }^{2}$ (Ma) } \\
\hline & $\mathbf{U}^{1}(\mathbf{p p m})$ & $T^{1}(p p m)$ & $\mathbf{T h} / \mathbf{U}$ & ${ }^{206} \mathrm{~Pb} /{ }^{238} \mathrm{U}$ & $\pm 2 \sigma$ & ${ }^{207} \mathrm{~Pb} /{ }^{235} \mathrm{U}$ & $\pm 2 \sigma$ & ${ }^{207} \mathrm{~Pb} /{ }^{206} \mathrm{~Pb}$ & $\pm 2 \sigma$ & Rho \\
\hline 16 & 404 & 136 & 0.29 & 70.0 & 2.0 & 74 & 10 & 312 & 244 & 0.47 \\
\hline 17 & 399 & 328 & 0.71 & 68.8 & 2.0 & 72 & 12 & 259 & 324 & 0.18 \\
\hline 18 & 186 & 76 & 0.35 & 70.0 & 2.0 & 76 & 10 & 294 & 266 & 0.40 \\
\hline 19 & 231 & 145 & 0.55 & 71.0 & 2.0 & 83 & 10 & 563 & 240 & -0.03 \\
\hline 20 & 311 & 266 & 0.74 & 69.1 & 2.0 & 82 & 16 & 473 & 362 & 0.37 \\
\hline 21 & 356 & 131 & 0.32 & 69.0 & 2.0 & 74 & 8 & 236 & 230 & 0.47 \\
\hline 22 & 329 & 204 & 0.54 & 66.6 & 1.8 & 71 & 12 & 227 & 298 & 0.57 \\
\hline 23 & 410 & 216 & 0.46 & 68.3 & 2.0 & 72 & 8 & 299 & 220 & 0.76 \\
\hline 24 & 203 & 129 & 0.55 & 69.0 & 2.0 & 76 & 10 & 333 & 262 & 0.16 \\
\hline 25 & 450 & 212 & 0.41 & 68.0 & 2.0 & 77 & 10 & 412 & 254 & 0.08 \\
\hline 26 & 259 & 138 & 0.47 & 69.0 & 2.0 & 76 & 12 & 363 & 306 & 0.21 \\
\hline 27 & 754 & 312 & 0.37 & 66.6 & 1.8 & 72 & 8 & 312 & 218 & 0.17 \\
\hline 29 & 256 & 243 & 0.85 & 68.0 & 4.0 & 93 & 46 & 792 & 928 & 0.79 \\
\hline 30 & 364 & 177 & 0.44 & 69.0 & 2.0 & 77 & 12 & 379 & 284 & 0.40 \\
\hline 31 & 425 & 281 & 0.60 & 69.0 & 2.0 & 74 & 8 & 329 & 238 & 0.01 \\
\hline 32 & 327 & 232 & 0.64 & 69.0 & 2.0 & 71 & 6 & 181 & 182 & 0.18 \\
\hline 33 & 511 & 370 & 0.65 & 71.0 & 2.0 & 120 & 24 & 1269 & 322 & 0.91 \\
\hline 34 & 185 & 125 & 0.61 & 70.0 & 2.0 & 70 & 14 & 58 & 346 & 0.26 \\
\hline 35 & 578 & 214 & 0.33 & 67.1 & 1.6 & 69 & 6 & 148 & 164 & 0.61 \\
\hline 36 & 318 & 300 & 0.84 & 68.1 & 2.0 & 70 & 6 & 263 & 212 & 0.09 \\
\hline 37 & 420 & 215 & 0.45 & 68.5 & 1.8 & 72 & 6 & 223 & 188 & 0.46 \\
\hline 38 & 391 & 330 & 0.74 & 68.7 & 1.8 & 71 & 6 & 236 & 154 & 0.59 \\
\hline 39 & 455 & 237 & 0.46 & 67.8 & 1.8 & 70 & 6 & 204 & 172 & 0.38 \\
\hline 40 & 429 & 148 & 0.30 & 66.4 & 1.6 & 74 & 12 & 327 & 328 & 0.35 \\
\hline 42 & 428 & 156 & 0.32 & 68.0 & 2.0 & 72 & 6 & 303 & 172 & 0.50 \\
\hline 43 & 429 & 298 & 0.61 & 70.9 & 1.8 & 71 & 6 & 124 & 164 & 0.64 \\
\hline 44 & 194 & 129 & 0.58 & 69.0 & 2.0 & 76 & 12 & 350 & 292 & 0.38 \\
\hline 45 & 589 & 265 & 0.40 & $\sim 65.1$ & 1.4 & 71 & 8 & 262 & 212 & 0.53 \\
\hline 47 & 264 & 203 & 0.68 & 66.8 & 1.8 & 79 & 8 & 488 & 170 & 0.41 \\
\hline 48 & 293 & 161 & 0.49 & 69.0 & 2.0 & 77 & 8 & 294 & 220 & 0.46 \\
\hline 49 & 618 & 393 & 0.56 & 67.6 & 2.0 & 87 & 20 & 652 & 410 & 0.75 \\
\hline 50 & 374 & 138 & 0.33 & 68.0 & 2.0 & 76 & 8 & 303 & 196 & 0.54 \\
\hline
\end{tabular}

${ }^{1} \mathrm{U}$ and Th concentrations are calculated employing an external standard zircon as in Paton et al., 2010, G3.

${ }^{2} 2 \sigma$ uncertainties propagated according to Paton et al., 2010, Geochemistry, Geophysics, Geosystems.

${ }^{207} \mathrm{~Pb} /{ }^{206} \mathrm{~Pb}$ ratios, ages and errors are calculated according to Petrus and Kamber (2012), Geostandards Geoanalyt Res.

Analyzed spots were 23 micrometers, using an analytical protocol modified from Solari et al. (2010), Geostandards Geoanalyt Res. Data measured employing a Thermo Xseries QICPMS coupled to a Resonetics, Resolution M050 excimer laser workstation.

$\sim$ Spot not included in mean age calculation. 

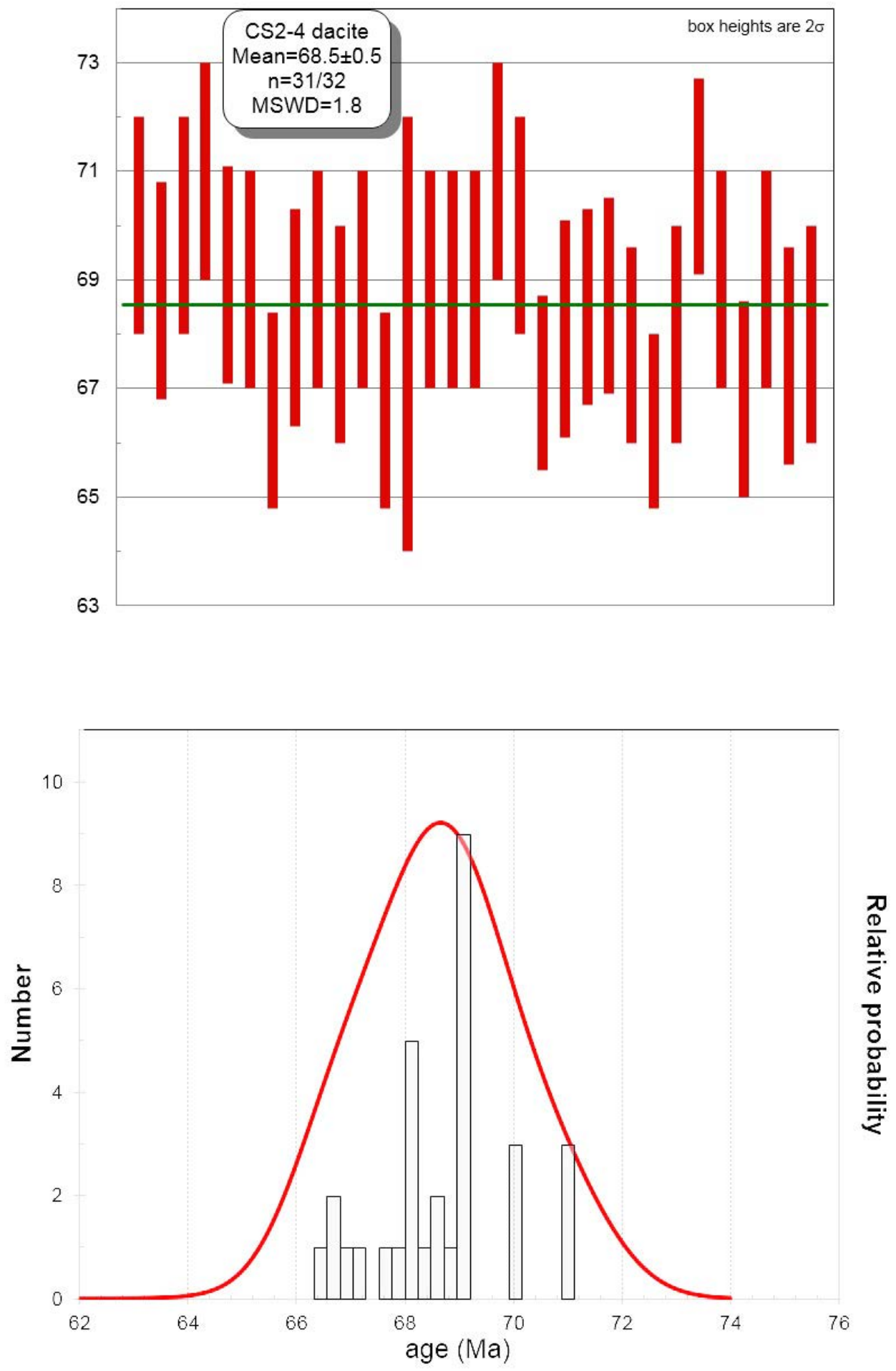


\begin{tabular}{|c|c|c|c|c|c|c|c|c|c|c|}
\hline \multirow{2}{*}{$\begin{array}{c}\text { CS2-35 } \\
\text { spots }\end{array}$} & \multicolumn{10}{|c|}{ CORRECTED AGES ${ }^{2}$ (Ma) } \\
\hline & $\mathbf{U}^{1}(\mathbf{p p m})$ & $\mathrm{Th}^{1}(\mathrm{ppm})$ & $\mathbf{T h} / \mathbf{U}$ & ${ }^{206} \mathrm{~Pb} /{ }^{238} \mathbf{U}$ & $\pm 2 \sigma$ & ${ }^{207} \mathbf{P b} /{ }^{235} \mathbf{U}$ & $\pm 2 \sigma$ & ${ }^{207} \mathrm{~Pb} /{ }^{206} \mathrm{~Pb}$ & $\pm 2 \sigma$ & Rho \\
\hline 1 & 297 & 169 & 0.57 & 71.0 & 2.0 & 109.0 & 10.0 & 930 & 140 & 0.28 \\
\hline 2 & 527 & 289 & 0.55 & 68.0 & 1.7 & 69.2 & 6.7 & 303 & 78 & 0.24 \\
\hline 3 & 140 & 74 & 0.53 & 73.0 & 3.0 & 116.0 & 24.0 & 1,310 & 220 & 0.20 \\
\hline 4 & 386 & 179 & 0.46 & 69.0 & 2.1 & 99.5 & 9.9 & 970 & 130 & 0.29 \\
\hline 5 & 381 & 261 & 0.69 & 69.4 & 2.1 & 74.3 & 9.6 & 450 & 110 & 0.23 \\
\hline 6 & 584 & 278 & 0.48 & 67.1 & 1.6 & 71.9 & 8.1 & 441 & 89 & 0.20 \\
\hline 7 & 306 & 155 & 0.51 & 69.7 & 2.1 & 79.0 & 10.0 & 690 & 110 & 0.22 \\
\hline 8 & 464 & 190 & 0.41 & 68.4 & 1.9 & 73.7 & 7.5 & 410 & 85 & 0.26 \\
\hline 9 & 177 & 131 & 0.74 & 21.1 & 1.1 & 75.0 & 12.0 & 2,820 & 190 & 0.31 \\
\hline 10 & 860 & 392 & 0.46 & 68.4 & 1.7 & 71.5 & 6.2 & 328 & 96 & 0.28 \\
\hline 11 & 339 & 167 & 0.49 & 69.8 & 3.3 & 73.5 & 8.6 & 410 & 110 & 0.39 \\
\hline 12 & 799 & 360 & 0.45 & 68.4 & 1.9 & 81.3 & 6.3 & 458 & 87 & 0.35 \\
\hline 13 & 523 & 1,017 & 1.94 & 485 & 9.8 & 484.0 & 18.0 & 496 & 36 & 0.46 \\
\hline 15 & 490 & 348 & 0.71 & 66.5 & 2.5 & 92.0 & 13.0 & 930 & 170 & 0.26 \\
\hline 16 & 316 & 303 & 0.96 & $* 15.1$ & 1.1 & 16.4 & 8.3 & 710 & 320 & 0.15 \\
\hline 17 & 511 & 302 & 0.59 & 68.3 & 2.9 & 145.0 & 13.0 & 1,680 & 120 & 0.43 \\
\hline 18 & 141 & 98 & 0.69 & 74.9 & 3.7 & 103.0 & 23.0 & 980 & 400 & 0.21 \\
\hline 20 & 282 & 232 & 0.82 & 66.6 & 2.2 & 68.3 & 7.8 & 650 & 150 & 0.28 \\
\hline 21 & 126 & 60 & 0.47 & 20.7 & 2.0 & 129.0 & 39.0 & 3,370 & 370 & 0.33 \\
\hline 22 & 377 & 204 & 0.54 & 69.4 & 2.8 & 77.0 & 13.0 & 610 & 180 & 0.23 \\
\hline 23 & 433 & 198 & 0.46 & 68.7 & 2.1 & 75.4 & 8.5 & 460 & 120 & 0.26 \\
\hline 24 & 367 & 246 & 0.67 & 67.4 & 2.4 & 100.0 & 14.0 & 1,160 & 220 & 0.24 \\
\hline 25 & 1,230 & 1,543 & 1.25 & $* 13.8$ & 0.5 & 14.1 & 2.7 & 610 & 200 & 0.17 \\
\hline 26 & 214 & 102 & 0.48 & 71.5 & 2.5 & 102.0 & 13.0 & 880 & 170 & 0.27 \\
\hline 27 & 114 & 59 & 0.52 & 19.6 & 1.9 & 112.0 & 22.0 & 3,070 & 160 & 0.45 \\
\hline 28 & 364 & 209 & 0.57 & 70.8 & 2.4 & 76.2 & 8.2 & 424 & 85 & 0.30 \\
\hline 29 & 279 & 95 & 0.34 & 69.4 & 2.4 & 75.5 & 9.8 & 470 & 110 & 0.27 \\
\hline 30 & 683 & 738 & 1.08 & $* 13.6$ & 0.7 & 19.0 & 4.9 & 1,130 & 180 & 0.20 \\
\hline 31 & 427 & 290 & 0.68 & 67.9 & 2.8 & 76.0 & 8.1 & 350 & 130 & 0.38 \\
\hline 33 & 268 & 130 & 0.49 & 67.7 & 2.5 & 81.0 & 11.0 & 790 & 160 & 0.26 \\
\hline 34 & 218 & 174 & 0.80 & 69.2 & 3.0 & 138.0 & 23.0 & 1,550 & 210 & 0.25 \\
\hline 35 & 192 & 190 & 0.99 & 18.0 & 2.2 & 61.0 & 15.0 & 2,650 & 310 & 0.51 \\
\hline
\end{tabular}

${ }^{1} \mathrm{U}$ and Th concentrations are calculated employing an external standard zircon as in Paton et al., 2010, G3.

${ }^{2} 2 \sigma$ uncertainties propagated according to Paton et al., 2010, Geochemistry, Geophysics, Geosystems.

${ }^{207} \mathrm{~Pb} /{ }^{206} \mathrm{~Pb}$ ratios, ages and errors are calculated according to Petrus and Kamber (2012), Geostandards Geoanalyt Res.

Analyzed spots were 23 micrometers, using an analytical protocol modified from Solari et al. (2010), Geostandards Geoanalyt Res.

Data measured employing a Thermo Xseries QICPMS coupled to a Resonetics, Resolution M050 excimer laser workstation.

* Spots included in mean age calculation. 

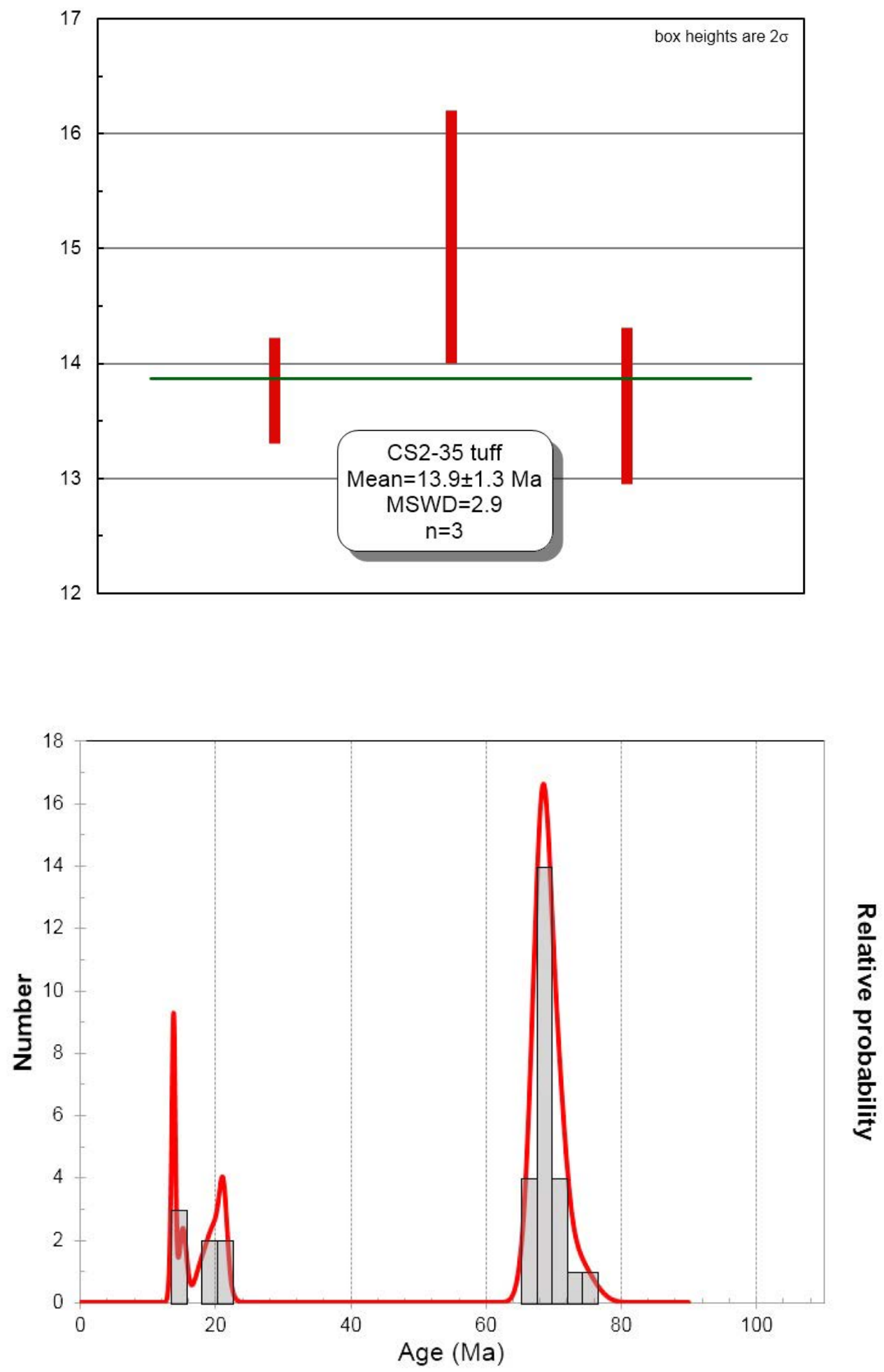


\begin{tabular}{|c|c|c|c|c|c|c|c|c|c|c|}
\hline \multirow{2}{*}{$\begin{array}{l}\text { CS-3 } \\
\text { spots }\end{array}$} & \multicolumn{10}{|c|}{ CORRECTED AGES ${ }^{2}$ (Ma) } \\
\hline & $\mathrm{U}^{1}(\mathrm{ppm})$ & $\mathbf{T h}^{1}(\mathbf{p p m})$ & $\mathbf{T h} / \mathbf{U}$ & ${ }^{206} \mathrm{~Pb} /{ }^{238} \mathrm{U}$ & $\pm 2 \sigma$ & ${ }^{207} \mathrm{~Pb} /{ }^{235} \mathrm{U}$ & $\pm 2 \sigma$ & ${ }^{207} \mathrm{~Pb} /{ }^{206} \mathrm{~Pb}$ & $\pm 2 \sigma$ & Rho \\
\hline 71 & 274 & 260 & 0.95 & $* 26.8$ & 2.9 & 45.0 & 37.0 & 1,180 & 370 & 0.11 \\
\hline 72 & 278 & 526 & 1.89 & $* 27.2$ & 1.1 & 44.4 & 5.0 & 1,310 & 120 & 0.35 \\
\hline 74 & 237 & 470 & 1.99 & $* 25.7$ & 1.0 & 32.9 & 4.6 & 780 & 150 & 0.28 \\
\hline 75 & 149 & 139 & 0.93 & 29.3 & 1.6 & 86.0 & 19.0 & 2,080 & 210 & 0.38 \\
\hline 76 & 203 & 385 & 1.90 & $* 27.2$ & 2.5 & 48.0 & 33.0 & 1,340 & 230 & 0.11 \\
\hline 77 & 65 & 76 & 1.18 & $* 26.4$ & 1.5 & 54.0 & 11.0 & 1,280 & 210 & 0.01 \\
\hline 78 & 145 & 168 & 1.16 & $* 26.5$ & 1.4 & 54.0 & 12.0 & 1,550 & 200 & 0.20 \\
\hline 79 & 157 & 218 & 1.39 & $* 27.3$ & 1.4 & 48.0 & 11.0 & 1,270 & 190 & 0.50 \\
\hline 80 & 258 & 529 & 2.05 & 24.8 & 1.1 & 32.8 & 4.7 & 1,060 & 130 & 0.30 \\
\hline 81 & 115 & 156 & 1.35 & $* 26.6$ & 1.3 & 45.8 & 7.6 & 1,170 & 150 & 0.32 \\
\hline 82 & 276 & 408 & 1.48 & $* 25.7$ & 0.9 & 28.5 & 4.6 & 760 & 120 & 0.21 \\
\hline 83 & 216 & 460 & 2.13 & $* 26.7$ & 1.6 & 53.3 & 8.8 & 1,290 & 190 & 0.35 \\
\hline 84 & 139 & 216 & 1.56 & $* 26.5$ & 1.2 & 33.6 & 5.8 & 890 & 130 & 0.17 \\
\hline 86 & 43 & 62 & 1.43 & $* 28.0$ & 1.7 & 71.0 & 16.0 & 2,080 & 240 & 0.23 \\
\hline 87 & 214 & 274 & 1.29 & $* 26.7$ & 1.2 & 60.1 & 5.9 & 1,720 & 110 & 0.49 \\
\hline 88 & 280 & 368 & 1.31 & $* 27.5$ & 2.6 & 36.0 & 42.0 & 810 & 360 & 0.49 \\
\hline 89 & 254 & 376 & 1.48 & 24.7 & 1.3 & 41.0 & 13.0 & 970 & 270 & 0.16 \\
\hline 91 & 102 & 137 & 1.34 & $* 28$ & 1.3 & 37.9 & 7.0 & 1,090 & 210 & 0.24 \\
\hline 92 & 137 & 154 & 1.12 & $* 27.4$ & 1.1 & 31.0 & 6.7 & 670 & 250 & 0.04 \\
\hline 93 & 133 & 195 & 1.47 & $* 26.9$ & 1.5 & 39.1 & 6.9 & 1,110 & 170 & 0.30 \\
\hline 94 & 151 & 258 & 1.71 & $* 26.7$ & 1.1 & 57.7 & 7.1 & 1,490 & 140 & 0.26 \\
\hline 96 & 201 & 352 & 1.75 & $* 27.9$ & 1.3 & 52.0 & 11.0 & 1,550 & 190 & 0.31 \\
\hline 97 & 895 & 1,899 & 2.12 & $* 25.6$ & 0.9 & 28.2 & 5.1 & 440 & 190 & 0.05 \\
\hline 98 & 249 & 496 & 1.99 & $* 28.0$ & 1.3 & 85.5 & 8.2 & 2,191 & 94 & 0.68 \\
\hline 101 & 184 & 381 & 2.07 & $* 26.3$ & 1.1 & 46.1 & 4.9 & 1,470 & 110 & 0.40 \\
\hline 102 & 108 & 104 & 0.97 & *26.6 & 1.5 & 34.0 & 12.0 & 1,320 & 240 & 0.17 \\
\hline 103 & 165 & 260 & 1.57 & $* 27.5$ & 1.0 & 30.9 & 5.6 & 750 & 170 & 0.20 \\
\hline 104 & 122 & 109 & 0.89 & $* 25.8$ & 1.3 & 37.9 & 7.3 & 1,080 & 160 & 0.43 \\
\hline 105 & 166 & 340 & 2.05 & *26.9 & 1.2 & 45.0 & 10.0 & 1,380 & 210 & 0.00 \\
\hline
\end{tabular}

${ }^{1} \mathrm{U}$ and Th concentrations are calculated employing an external standard zircon as in Paton et al., 2010, G3.

${ }^{2} 2 \sigma$ uncertainties propagated according to Paton et al., 2010, Geochemistry, Geophysics, Geosystems.

${ }^{207} \mathrm{~Pb} /{ }^{206} \mathrm{~Pb}$ ratios, ages and errors are calculated according to Petrus and Kamber (2012), Geostandards Geoanalyt Res.

Analyzed spots were 23 micrometers, using an analytical protocol modified from Solari et al. (2010), Geostandards Geoanalyt Res. Data measured employing a Thermo Xseries QICPMS coupled to a Resonetics, Resolution M050 excimer laser workstation.

* Spots included in mean age calculation. 

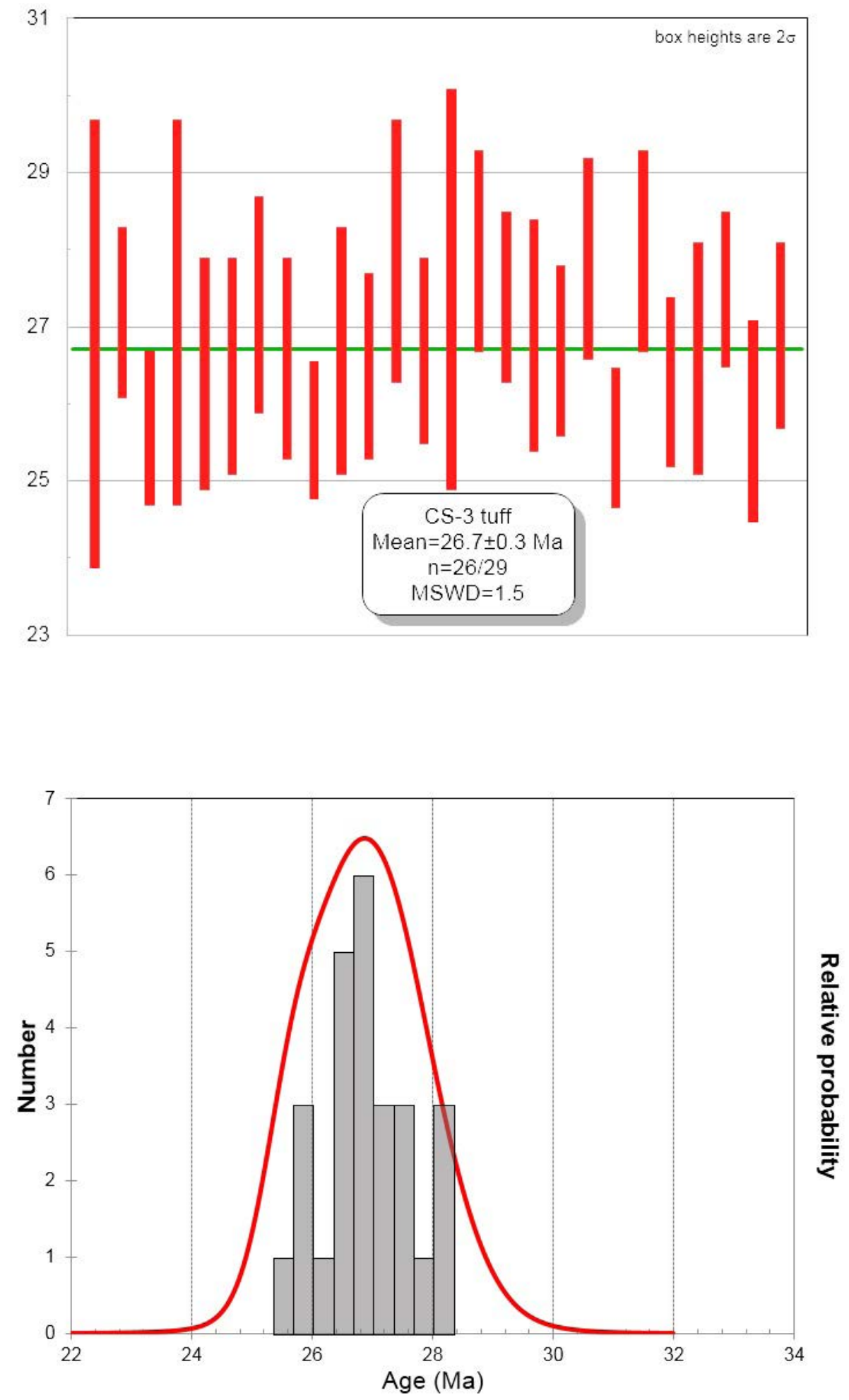


\begin{tabular}{|c|c|c|c|c|c|c|c|c|c|c|}
\hline \multirow{2}{*}{$\begin{array}{c}\text { HC-07 } \\
\text { spots }\end{array}$} & \multicolumn{10}{|c|}{ CORRECTED AGES ${ }^{2}$ (Ma) } \\
\hline & $\mathbf{U}^{1}(\mathbf{p p m})$ & $\mathbf{T h}^{1}(\mathbf{p p m})$ & $\mathbf{T h} / \mathbf{U}$ & ${ }^{206} \mathrm{~Pb} /{ }^{238} \mathbf{U}$ & $\pm 2 \sigma$ & ${ }^{207} \mathbf{P b} /{ }^{235} \mathbf{U}$ & $\pm 2 \sigma$ & ${ }^{207} \mathrm{~Pb} /{ }^{206} \mathrm{~Pb}$ & $\pm 2 \sigma$ & Rho \\
\hline 71 & 263 & 152 & 0.58 & 68.7 & 1.4 & 85.9 & 6.5 & 690 & 120 & 0.26 \\
\hline 72 & 315 & 185 & 0.59 & 64.6 & 1.2 & 77.0 & 6.4 & 585 & 97 & 0.22 \\
\hline 73 & 240 & 123 & 0.51 & 50.4 & 0.8 & 52.3 & 5.8 & 340 & 150 & 0.13 \\
\hline 74 & 424 & 151 & 0.36 & 65.6 & 1.0 & 77.6 & 4.2 & 521 & 54 & 0.28 \\
\hline 75 & 210 & 162 & 0.77 & 54.1 & 1.3 & 121 & 13.0 & 1,700 & 150 & 0.21 \\
\hline 76 & 192 & 105 & 0.55 & 53.3 & 1.3 & 94.9 & 5.3 & 1,341 & 66 & 0.43 \\
\hline 77 & 611 & 130 & 0.21 & 68.9 & 1.0 & 91.1 & 6.0 & 712 & 82 & 0.22 \\
\hline 78 & 235 & 168 & 0.71 & 50.2 & 1.2 & 57.3 & 8.6 & 740 & 170 & 0.15 \\
\hline 79 & 197 & 218 & 1.11 & *46.9 & 1.6 & 72.0 & 16.0 & 1,070 & 210 & 0.14 \\
\hline 80 & 485 & 201 & 0.41 & 63.3 & 1.3 & 65.1 & 5.6 & 420 & 95 & 0.23 \\
\hline 81 & 102 & 79 & 0.77 & 51.7 & 1.9 & 125 & 22.0 & 2,110 & 170 & 0.20 \\
\hline 83 & 621 & 340 & 0.55 & 65.1 & 1.0 & 70.8 & 3.5 & 322 & 54 & 0.29 \\
\hline 85 & 397 & 256 & 0.64 & $* 48.9$ & 0.8 & 49.0 & 3.2 & 357 & 78 & 0.25 \\
\hline 86 & 594 & 238 & 0.40 & $* 49.3$ & 0.9 & 62.6 & 4.8 & 560 & 110 & 0.23 \\
\hline 87 & 218 & 148 & 0.68 & 65.2 & 1.8 & 90.0 & 13.0 & 920 & 160 & 0.18 \\
\hline 88 & 229 & 106 & 0.46 & 66.9 & 1.4 & 84.5 & 8.5 & 610 & 140 & 0.20 \\
\hline 89 & 244 & 148 & 0.60 & 50.7 & 1.4 & 81.0 & 15.0 & 1,190 & 180 & 0.14 \\
\hline 90 & 356 & 142 & 0.40 & 65.2 & 1.4 & 66.3 & 5.4 & 225 & 93 & 0.25 \\
\hline 91 & 497 & 300 & 0.60 & 59.6 & 2.2 & 82.2 & 7.3 & 870 & 100 & 0.39 \\
\hline 93 & 444 & 240 & 0.54 & 64.4 & 1.4 & 80.6 & 3.7 & 618 & 50 & 0.44 \\
\hline 94 & 197 & 174 & 0.88 & 65.5 & 1.4 & 70.8 & 7.0 & 490 & 130 & 0.21 \\
\hline 95 & 318 & 264 & 0.83 & $* 49.1$ & 1.0 & 51.2 & 3.5 & 339 & 86 & 0.27 \\
\hline 96 & 247 & 246 & 1.00 & $* 45.5$ & 1.7 & 74.0 & 15.0 & 1,210 & 220 & 0.17 \\
\hline 97 & 352 & 248 & 0.70 & 64.9 & 1.3 & 66.0 & 13.0 & 410 & 210 & 0.10 \\
\hline 98 & 198 & 103 & 0.52 & 50.2 & 1.6 & 75.2 & 9.2 & 1,050 & 140 & 0.25 \\
\hline 99 & 340 & 211 & 0.62 & 67.6 & 1.3 & 99.0 & 7.4 & 957 & 93 & 0.24 \\
\hline 100 & 850 & 394 & 0.46 & 62.9 & 1.2 & 82.3 & 3.8 & 703 & 39 & 0.40 \\
\hline 102 & 117 & 107 & 0.91 & $* 47.6$ & 1.5 & 92.0 & 16.0 & 1,530 & 170 & 0.17 \\
\hline 104 & 185 & 137 & 0.74 & $* 49.8$ & 1.6 & 70.4 & 8.0 & 940 & 150 & 0.27 \\
\hline 105 & 204 & 256 & 1.25 & $* 49.8$ & 1.6 & 77.0 & 14.0 & 1,130 & 190 & 0.17 \\
\hline
\end{tabular}

${ }^{1} \mathrm{U}$ and Th concentrations are calculated employing an external standard zircon as in Paton et al., 2010, G3.

${ }^{2} 2 \sigma$ uncertainties propagated according to Paton et al., 2010, Geochemistry, Geophysics, Geosystems.

${ }^{207} \mathrm{~Pb} /{ }^{206} \mathrm{~Pb}$ ratios, ages and errors are calculated according to Petrus and Kamber (2012), Geostandards Geoanalyt Res.

Analyzed spots were 23 micrometers, using an analytical protocol modified from Solari et al. (2010), Geostandards Geoanalyt Res.

Data measured employing a Thermo Xseries QICPMS coupled to a Resonetics, Resolution M050 excimer laser workstation.

* Spots included in mean age calculation. 

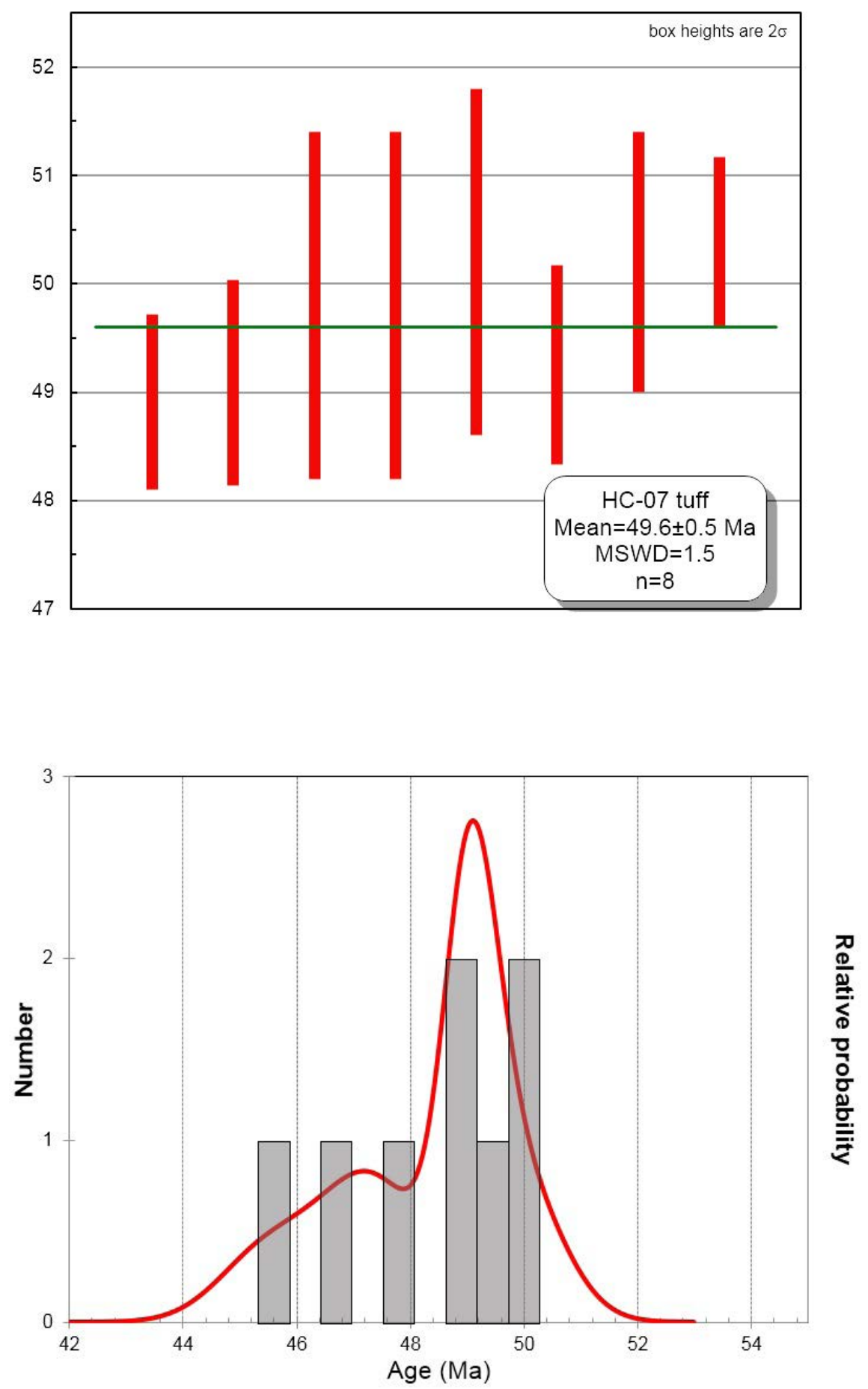